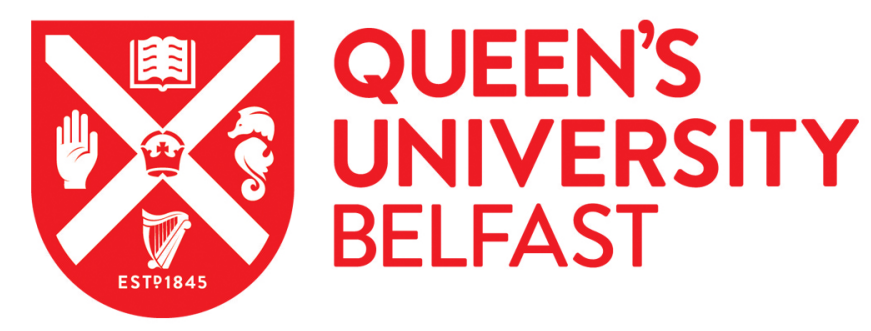

\title{
The relationship between highly visual social media and young people's mental health: A scoping review
}

McCrory, A., Best, P., \& Maddock, A. (2020). The relationship between highly visual social media and young people's mental health: A scoping review. Children and Youth Services Review.

https://doi.org/10.1016/j.childyouth.2020.105053

Published in:

Children and Youth Services Review

Document Version:

Peer reviewed version

Queen's University Belfast - Research Portal:

Link to publication record in Queen's University Belfast Research Portal

Publisher rights

Copyright 2020 Elsevier.

This manuscript is distributed under a Creative Commons Attribution-NonCommercial-NoDerivs License

(https://creativecommons.org/licenses/by-nc-nd/4.0/), which permits distribution and reproduction for non-commercial purposes, provided the author and source are cited.

\section{General rights}

Copyright for the publications made accessible via the Queen's University Belfast Research Portal is retained by the author(s) and / or other copyright owners and it is a condition of accessing these publications that users recognise and abide by the legal requirements associated with these rights.

Take down policy

The Research Portal is Queen's institutional repository that provides access to Queen's research output. Every effort has been made to ensure that content in the Research Portal does not infringe any person's rights, or applicable UK laws. If you discover content in the Research Portal that you believe breaches copyright or violates any law, please contact openaccess@qub.ac.uk. 


\section{Introduction}

Social network sites (SNS) such as Facebook, Twitter, Instagram and Snapchat, are the most commonly utilised online platforms among young people (Perloff, 2014). Their widespread availability, whether through a smartphone, tablet or desktop computer, coupled with alluring attributes such as social connectedness (Valkenburg and Peter, 2007) and effortless communication regardless of geographical location (Sawyer, 2011), have captivated billions of users throughout the world with many habitually using SNS for large portions of daily life (Rideout et al., 2010; Sample, 2019).

In a recent report from OfCom (UK), 99\% of 12-15-year olds are online for an average of 20.5 hours per week with $69 \%$ creating an online profile and utilising a social media platform (OfCom, 2019). This figure has drastically increased over the years with statistics indicating a $256 \%$ growth in the time spent online, from 8 hours per week recorded with the same age group in 2005 (OfCom, 2011). The number of social media users worldwide is documented as 3.5 billion, an escalation of 9\% year-on-year (Global Digital Report, 2019). East Asia and North America are reported to have the most social media users with a penetration rate of $70 \%$, followed by Northern Europe at 67\% (Clement, 2019).

Uploading visual content, mainly photographs or videos, is an integral component of interaction on popular highly visual social media platforms (HVSM) such as Instagram and Snapchat. In addition, many HVSM platforms enable users to edit visual content before they upload it. Research into the visual aspects of online communication and interaction has lagged behind the analysis of popular, predominantly text-driven social media.

This paper aims to conduct a scoping review of the current literature invested in the relationship between highly visual social media and young people's mental health. The five specific objectives of this scoping review are to: 
1. Explore what HVSM platforms have a body of existing research in relation to young people's mental health.

2. Explore the age range and gender of study participants in existing research.

3. Explore what study methods have been implemented when researching the relationship between HVSM and young people's mental health.

4. Explore relationships between inherent features of HVSM and young people's mental health, specifically time spent using HVSM, the act of taking selfies and the use of filters on images.

5. Explore what researchers have used as theoretical frameworks to inform their data interpretation.

\section{Context}

\section{1: Young People and Mental Health}

Mental health encompasses an individual's emotional, psychological and social wellbeing (Galderisi et al., 2015). According to the World Health Organisation (WHO), mental health is:

... a state of wellbeing in which the individual realises his or her own abilities, can cope with the normal stresses of life, can work productively and fruitfully and is able to make a contribution to his or her own community (WHO, 2014)

National Health Service (NHS) figures reveal that almost 400,000 young people under the age of 18 in England are in contact with the health service for mental health problems. In the same report, the number of young people referred by GP's for conditions such as anxiety 
and depression is a third higher than two years previously (NHS Digital, 2018). Action Mental Health (AMH) described Northern Ireland (NI) as having 'catastrophic levels' of mental illhealth (AMH, 2018). Statistics indicate that NI has a 25\% higher overall prevalence of mental health problems than England and has the highest rates for self-harm and suicide in the UK (Mental Health Foundation, 2016).

This is not only a national problem; a similar rise in concern over the mental wellbeing of young people is evident across the world. In 2018, 24.2\% of young people in Australia experienced psychological distress, a statistic that has risen 18.7\% from 2012 (Mission Australia, 2019). The rate of individuals in the United States reporting symptoms consistent with major depression in the last 12 months has increased by $52 \%$ in adolescents from 2005 2017. Correspondingly, young people experiencing psychological distress has increased by 71\% from 2008-2017 (American Psychological Association, 2019).

Early research exploring the emotional and psychological impact of social media, particularly with Facebook, attributed poor mental health with excessive use (Jelenchick et al., 2013; McCord et al., 2014). Conversely, other research presents positive connections with Facebook use. Findings showed increased levels of self-esteem and confidence in users who post to their Facebook profile (Gonzales and Hancock, 2011). Best et al. (2014) corroborate the mixed findings in this area. Their review purports a 'wealth of contradictory evidence suggesting both harmful and beneficial aspects' of social media usage and confirms the need for further research into the relationship between SNS and adolescent wellbeing. 


\section{2: Highly Visual Social Media}

HVSM applications prioritise online distribution of rich visual content using videos and photographs and permit digital modification of visuals prior to upload with an array of embedded filters (Marengo et al., 2018). HVSM applications endorse the taking and sharing of 'Selfies,' a self-portrait photograph of oneself or of oneself with others, usually captured on a mobile device held at arm's length (Sorokowska et al., 2016). Selfies are becoming increasingly popular with quantitative research indicating that every third picture taken is a selfie (Chiu, 2018). Srivastava et al.'s (2018) research attribute this popularity to a growing need for social approval and positive affirmation. The mass market has responded to the selfie trend with the creation of various selfie sticks, and mobile phone companies continue to modify their handsets to appeal to 'the selfie culture' by including fashionable features such as wideangle front camera and integrated selfie flashlight.

HVSM platforms compete with each other for utmost usage and user attention (Shane, 2017). This has resulted in Facebook, Instagram and Snapchat all introducing a new 'Stories' feature. All three platforms have embedded 'stories' within their application to encourage users to share additional moments of their daily life (Constine, 2018). The posts on a story disappear after a 24-hour timeframe permitting users to share more visuals momentarily rather than 'permanently' on their profile feed (Constine, 2017). Stories rely on time-intensive photographs and videos to reel in an audience. They offer the capacity to illustrate a user's existence in the virtual world in much more detail than traditional 'wall' posts, meaning increased time and effort is spent on the act of taking, editing and posting visual content (House of Commons, 2019).

With these new and enticing features, users of social media are continuing to increase. Global figures indicate that 321 million new people joined social media in 2019, an increase 
of 9\% (Digital 2020 Report). As of January 2019, Statista reported that the top 5 countries that have accumulated the most time spent on social media are the United Arab Emirates at 99\%, Taiwan at 89\%, South Korea at 85\%, Singapore at 79\% and Hong Kong at 78\% (Statista, 2019).

With online social media usage at an all-time high (Battisby, 2019), the impact of engagement with these activities on young people's mental health and wellbeing is not fully understood, particularly concerning HVSM. It was decided to undertake a scoping review of existing literature, as this methodology is investigative in nature and more all-encompassing than other methodological approaches. Scoping reviews aim to map literature on a specific topic and offer the ideal opportunity to recognise key concepts and gaps in the research (Daudt et al., 2013). This study aims to identify existing literature examining the relationship between the use of highly visual social media and young people's mental health.

\section{Theoretical Considerations}

According to Goffman (1959), "we are all just actors trying to control and manage our public image. We act based on how others might see us" (p.22). Goffman's Dramaturgical Theory is a sociological perspective that is primarily concerned with how people conduct and manage everyday interactions in social situations (Goffman, 1959; Manning, 2005; Hendricks et al., 2016). The epitome of this approach is the juxtaposition of the human world with the theatrical stage, particularly the dichotomy between an actor's front stage and backstage experience. For Goffman, being front stage allows individuals to present an idealised version of themselves as opposed to an authentic version. Backstage behaviour is paralleled with an actor's life behind the curtain, off-stage and out of character (Kerrigan and Hart, 2016). 
It has been suggested that the proliferation of social media sites has provided another 'stage' and opportunity for people to curate an online persona, engaging in strategic selfpresentation (Fitzpatrick et al., 2016; Ellison et al., 2006). With the inherent features of highly visual social media platforms, it will be interesting to discover if current research explores the relationship between the use of these platforms and young people's mental health through the lens of this theoretical framework.

Baudrillard's theory of hyperreality argues that 'reality' has been replaced with 'simulation;' a blending of reality and representation of reality, where there is no clear indication of where the former stops and the latter begins (Devika, 2016). Hyperreality is seen as a condition in which what is real and what is fiction are seamlessly blended together.

As social media has developed to include a more visual dimension, users of these platforms are confronted with a new set of virtually unattainable standards to aspire to (Volkinburg, 2018). Filters and other modes of digital alteration are forcing users to strive towards sharing images and videos that portray unreachable, non-human qualities. Baudrillard's theory of hyperrealism argues that human beings are unable to see the world as it really is. It could be argued that the growth of highly visual social media has contributed to blurred perceptions between the 'real' and the constructed, to the extent whereby users can no longer distinguish between the two.

This scoping review will explore if current research on highly visual social media investigates this disconnection from a tangible reality and whether there is any relationship with young people's mental health. 


\section{Methods}

Arksey and O’Malley's (2005) five-staged framework for scoping reviews, revised by Levac et al. (2010), was used to structure the process and permit a thorough literature search as shown in Table 1.

Table 1

Methodological Framework for Scoping Reviews and Revisions

\begin{tabular}{|c|c|c|c|}
\hline & $\begin{array}{l}\text { Arksey and O’Malley's } \\
\text { framework stage }\end{array}$ & $\begin{array}{l}\text { Description of the scoping review } \\
\text { stage }\end{array}$ & Levac et al.'s revisions \\
\hline 1 & $\begin{array}{l}\text { Identifying the } \\
\text { Research Question }\end{array}$ & $\begin{array}{l}\text { Research questions should be } \\
\text { broad in nature as they seek to } \\
\text { provide a breadth of coverage }\end{array}$ & $\begin{array}{l}\text { A clearly articulated } \\
\text { research question is needed } \\
\text { to guide the scope of } \\
\text { inquiry }\end{array}$ \\
\hline 2 & $\begin{array}{l}\text { Identifying Relevant } \\
\text { Studies }\end{array}$ & $\begin{array}{l}\text { Develop a decision plan for where } \\
\text { to search, which terms to use, } \\
\text { which sources, time span and } \\
\text { language }\end{array}$ & $\begin{array}{l}\text { Research question and } \\
\text { purpose should guide } \\
\text { decision making around the } \\
\text { scope of the study. When } \\
\text { limiting scope is } \\
\text { unavoidable, justify } \\
\text { decisions. }\end{array}$ \\
\hline 3 & Study Selection & $\begin{array}{l}\text { Study selection involves post hoc } \\
\text { inclusion and exclusion criteria. } \\
\text { These criteria are based on the } \\
\text { specifics of the research question }\end{array}$ & $\begin{array}{l}\text { Should be an iterative } \\
\text { process: search literature, } \\
\text { refine search strategy and } \\
\text { review articles for inclusion }\end{array}$ \\
\hline
\end{tabular}




\begin{tabular}{|l|l|l|l|}
\hline 4 & Charting the Data & $\begin{array}{l}\text { A data charting form is developed } \\
\text { and used - a narrative review or } \\
\text { descriptive-analytical method is } \\
\text { used to extract information }\end{array}$ & $\begin{array}{l}\text { Charting should be } \\
\text { considered an iterative } \\
\text { process in which } \\
\text { researchers continually } \\
\text { extract data and update a } \\
\text { data-charting form }\end{array}$ \\
\hline 5 & $\begin{array}{l}\text { Collating, Summarising } \\
\text { and Reporting the }\end{array}$ & $\begin{array}{l}\text { Thematic analysis is presented. } \\
\text { Clarity and consistency are } \\
\text { Results }\end{array}$ & $\begin{array}{l}\text { Three stages - analysis } \\
\text { report the results, consider } \\
\text { the meaning of the findings } \\
\text { as they relate to the overall } \\
\text { study purpose }\end{array}$ \\
\end{tabular}

Note: Adapted from "Scoping studies: Towards a Methodological Framework," by Arksey and O'Malley, 2005, p24 and "Scoping studies: advancing the methodology," by Levac et al., 2010, p69

\section{1: Identifying the Research Question}

The focus of this scoping review was to examine literature in the field of highly visual social media with particular emphasis placed on its influence on young people's mental health. The following research question was designed: what is the relationship between highly visual social media and young people's mental health? Marengo et al.'s (2018) definition of HVSM helped formulate the search terms:

These social media platforms (HVSM) mainly focus on sharing user-generated visual content, such images and short videos, and allow the use of filters to modify and improve users' looks before upload. (Marengo et al., 2018, p64). 


\section{2: Identifying Relevant Studies}

Suitable literature was identified using clear search terms based on Marengo et al.'s (2018) definition of highly visual social media. Multiple variations of these terms were included to ensure the search was as comprehensive as possible (Arksey and O'Malley, 2005; Levac et al., 2010). A university librarian with a speciality in databases was consulted during this process and was able to offer advice on the selection of appropriate search terms, the use of Boolean operators to expand and narrow searches and the choice of suitable databases to explore.

Three search strings were generated as depicted in Table 2.

Table 2

Database Search Terms

\begin{tabular}{|l|l|}
\hline & Search term/phrase \\
\hline 1 & snapchat \\
\hline 2 & instagram \\
\hline 3 & facebook \\
\hline 4 & "highly visual social media" \\
\hline 5 & "image based social media" \\
\hline 6 & selfie \\
\hline 7 & self-image \\
\hline 8 & filter \\
\hline 9 & "digital manipulation" \\
\hline 10 & "digitally enhanced" \\
\hline 11 & "digitally modified" \\
\hline 12 & "digitally altered" \\
\hline 13 & 1 OR 2 OR 3 OR 4 OR 5 OR 6 OR 7 OR 8 OR 9 OR 10 OR 11 OR 12 \\
\hline 14 & adolescen* \\
\hline 15 & teen \\
\hline 16 & "young people" \\
\hline 17 & "young person" \\
\hline 18 & youth \\
\hline 19 & child \\
\hline 20 & children \\
\hline 21 & 14 OR 15 OR 16 OR 17 OR 18 OR 19 OR 20 \\
\hline 22 & anxiety \\
\hline 23 & "self-esteem" \\
\hline 24 & confidence \\
\hline & \\
\hline
\end{tabular}




\begin{tabular}{|l|l|}
\hline 25 & "self-confidence" \\
\hline 26 & depression \\
\hline 27 & mood \\
\hline 28 & stress \\
\hline 29 & fear \\
\hline 30 & wellbeing \\
\hline 31 & "mental health" \\
\hline 32 & 22 OR 23 OR 24 OR 25 OR 26 OR 27 OR 28 OR 29 OR 30 OR 31 \\
\hline 33 & 13 AND 21 AND 32 \\
\hline
\end{tabular}

Twelve electronic databases were selected, however, after a preliminary search, three indicated no literature matches and were therefore excluded, resulting in nine included databases (see Table 3). Hand searching of reference lists was also conducted along with a general internet browser search (Google Scholar) to capture any grey literature or additional publications. The literature search took place within a seven-day timeframe from $15^{\text {th }}-22^{\text {nd }}$ February 2019.

Table 3

The Nine Included Databases

\begin{tabular}{|l|l|}
\hline Database & Background \\
\hline Child Development \& & This bibliographic database is today's source for references to \\
the current and historical literature related to growth and \\
development of children through the age of 21.
\end{tabular}




\begin{tabular}{|c|c|}
\hline Social Policy and Practice & $\begin{array}{l}\text { SPP brings together information from six of the UK's } \\
\text { leading collections of social policy and practice resources. }\end{array}$ \\
\hline PubMed & $\begin{array}{l}\text { PubMed comprises more than } 29 \text { million citations for } \\
\text { biomedical literature from MEDLINE, life science journals } \\
\text { and online books. Citations may include links to full-text } \\
\text { content from PubMed Central and publisher websites. }\end{array}$ \\
\hline Medline & $\begin{array}{l}\text { MEDLINE is the U.S. National Library of } \\
\text { Medicine } ®(N L M) \text { premier bibliographic database that } \\
\text { contains more than } 25 \text { million references to journal articles in } \\
\text { life sciences with a concentration on biomedicine. }\end{array}$ \\
\hline SCOPUS & $\begin{array}{l}\text { Scopus is a citation database of peer-reviewed literature: } \\
\text { scientific journals, books and conference proceedings. } \\
\text { Delivering a comprehensive overview of the world's research } \\
\text { output in the fields of science, technology, medicine, social } \\
\text { sciences, and arts and humanities, Scopus features smart } \\
\text { tools to track, analyse and visualize research. }\end{array}$ \\
\hline British Education Index & $\begin{array}{l}\text { This database covers all aspects of educational policy and } \\
\text { administration, evaluation and assessment, technology and } \\
\text { special educational needs. Indexing British } \\
\text { education journals, theses and more, this resource is } \\
\text { searchable by educational level and age group. }\end{array}$ \\
\hline Ethos & $\begin{array}{l}\text { Ethos is a bibliographic database and union catalogue of } \\
\text { electronic theses provided by the British Library, the } \\
\text { National Library of the United Kingdom. It provides access }\end{array}$ \\
\hline
\end{tabular}


to approximately 500,000 doctoral theses from over $140 \mathrm{UK}$ higher education institutions.

\section{3: Study Selection}

Literature was included if it explored any relationship between visual social media and young people's mental health. For this scoping review, 'visual social media' was refined and specified as 'Facebook,' 'Instagram' and 'Snapchat.' Instagram and Snapchat were automatically included as they are deemed 'highly visual social media' due to their explicit visual emphasis (Marengo et al., 2018) however since Facebook promotes an amalgam of images and text in myriad forms (Highfield and Leaver, 2016), careful consideration had to be given to its inclusion. After a preliminary search, it was clear that the literature surrounding 'highly visual social media' is scarce and removing Facebook from the search could hinder the breadth of the scoping review. Levac et al. (2010) recommend that "researchers ensure decisions surrounding feasibility do not compromise their ability to answer the research question or achieve the study purpose" (p5). As a result, it was decided to include Facebook as a 'visual social media' platform but to restrict the literature search from 2010 onwards as this marked the inception of the highly visual social media platform, Instagram, closely followed by Snapchat, 2011.

The first search yielded 7710 records in total. After removing all duplicate finds, an initial screening of titles and abstracts ensued. All authors met prior to screening to agree on a set of inclusion and exclusion criteria. The principal author completed the first round of screening, and this process was reviewed by co-authors to ensure inclusion criteria were consistently applied. Any records not pertaining to this agreed list of inclusion criteria were removed (see Table 4). Clear inclusion and exclusion criteria were categorised according to the 
broad Population - Concept - Context (PCC) mnemonic recommended by the Joanna Briggs

Institute for scoping reviews (Peters et al., 2015).

Table 4

Inclusion and Exclusion Criteria

\begin{tabular}{|l|}
\hline INCLUSION CRITERIA \\
\hline POPULATION
\end{tabular}

\begin{tabular}{|c|l|}
\hline 1 & Studies involving any gender \\
\hline 2 & Studies including young people: between $12-18$ years must feature \\
\hline
\end{tabular}

\section{CONCEPT}

\begin{tabular}{|c|l|}
\hline 3 & Visual Social Media, specifically Snapchat, Instagram and Facebook \\
\hline 4 & Studies exploring self-photography, selfies or self-presentation on Criterion 3 \\
\hline 5 & Studies exploring photo editing or digitally altered images on Criterion 3 \\
\hline 6 & Studies exploring mental health or any aspects of mental health within Criterion 3 \\
\hline 7 & Studies exploring body image, body dissatisfaction with Criterion $3 \& 4$ \\
\hline CONTET
\end{tabular}

\section{CONTEXT}

\begin{tabular}{|c|l|}
\hline 8 & Studies published from 2010 onwards \\
\hline 9 & Studies in the English Language \\
\hline 10 & Studies conducted in any country \\
\hline 11 & Studies set in any environment \\
\hline 12 & Empirical Studies using any methods \\
\hline EXCLUSION CRITERIA
\end{tabular}

EXCLUSION CRITERIA

POPULATION

\begin{tabular}{|l|l}
1 & Studies exclusively focused on 19 years or older
\end{tabular}

\section{CONCEPT}




\begin{tabular}{|c|l|}
\hline 2 & Twitter or any other Social Media platform outside Inclusion Criteria 3 \\
\hline 3 & Studies relating to digital marketing, advertisements and business promotion \\
\hline 4 & Studies with political orientation, social rank, empowerment themes \\
\hline CONTEXT \\
\hline 5 & Studies published prior to 2010 \\
\hline 6 & Studies in a language other than English \\
\hline 7 & Theoretical Studies: Reviews, Newspaper Articles \\
\hline
\end{tabular}

Note: Adapted from “Guidance for conducting systematic scoping reviews, ” 2015, p142

Two hundred thirty-nine full-text articles underwent a second screening process where the principal author examined the study participants, methods and results in more detail alongside exclusion criteria. The other two contributing authors separately reviewed provisional sets of papers deemed appropriate for inclusion. Through an iterative process over several meetings, a consensus was reached on 25 papers to be included in the analysis.

\section{4: Charting the Data}

The fourth stage of Arksey and O'Malley's (2005) framework involves extracting the data from the included studies. Armstrong et al.'s criteria (2011) for scoping review data collection was utilised to formulate a table that comprised of 1.Authors, 2. Year of Publication, 3.Study Location, 4. Study Population, 5. Aims of the Study, 6. Overview of Methods and 7. Summary of Results. This table enabled efficient identification of commonalities, themes and gaps in the literature. Details of data extracted from the included studies are provided in Appendix 4. 


\section{5: Summarising and Reporting the Findings}

The fifth stage of Arksey and O'Malley's (2005) framework involves the process of summarising and reporting the findings. The Preferred Reporting Items for Systematic Reviews and Meta-Analysis (PRISMA) (Moher et al., 2008) flow diagram was used to report the selection process, as shown in Figure 1. After the data extraction table was put together, all authors met on several occasions to discuss key findings and identify patterns within the data. The principal author then prepared an initial draft summary of findings which was further discussed and refined until consensus was reached.

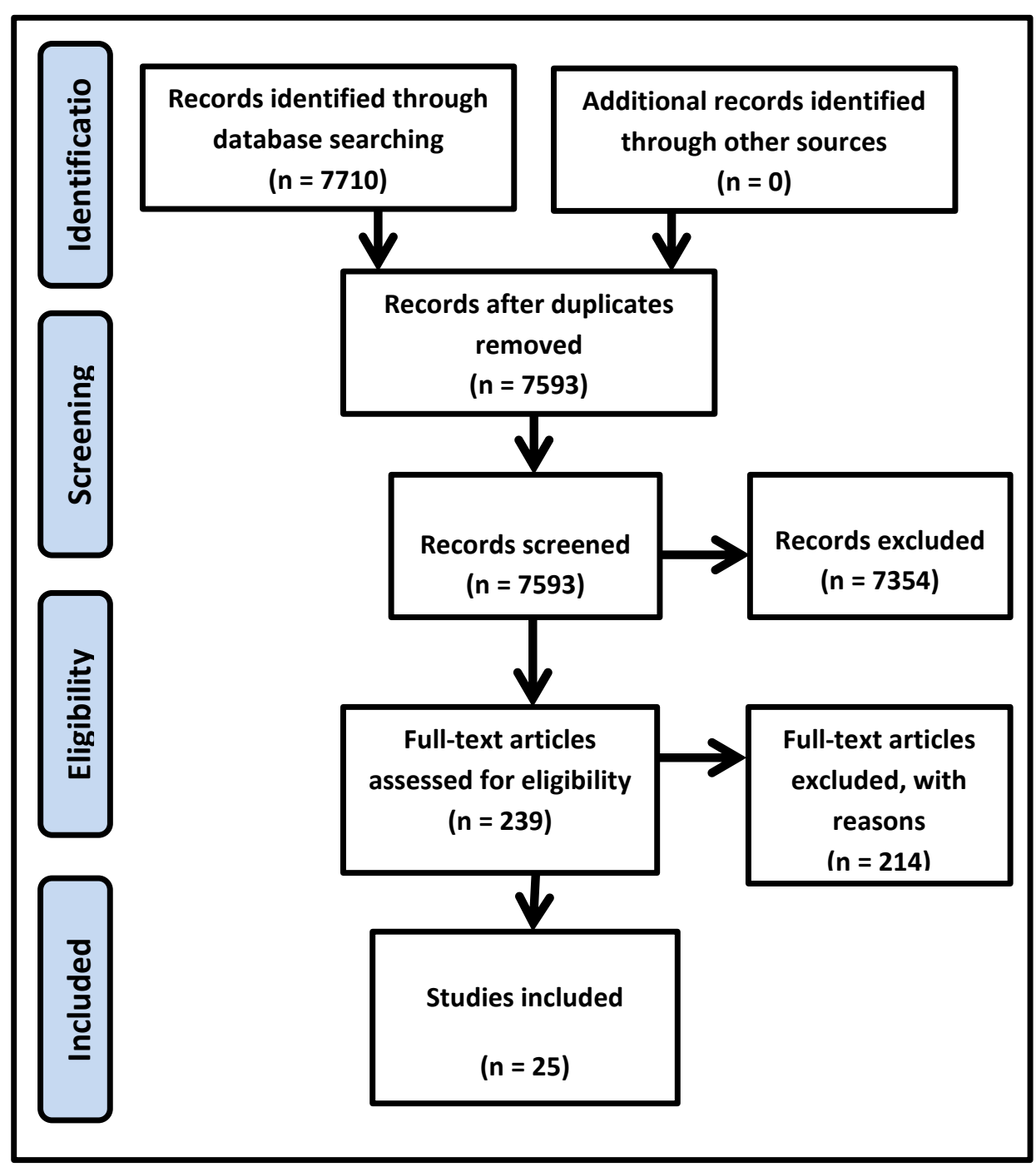

Figure 1. PRISMA diagram depicting the selection process 


\section{Findings}

\section{1: Demographics, Temporal and Geographical Distribution}

Participants included in $68 \%$ of studies included both male and female participants, with $32 \%$ of studies exclusively focusing on female gender. Studies were excluded if they did not include participants in the $14-18$ age range. $60 \%$ of papers were entirely within these parameters; however, $40 \%$ included 14-18-year-old participants plus other age ranges.

The literature search was refined to studies published post-2010. Across the 25 selected studies, none were published before 2013. $16 \%$ of papers were published $2013-2014.40 \%$ of papers were published 2015-2017. 48\% of papers were published 2018-2019 indicating a growth of interest in this field with particular attention being invested presently.

Geographical locations varied across the selected studies; however, there were two countries where significant proportions of the research featured. Nearly a quarter $(24 \%)$ of the research was carried out in the United States, closely followed by a fifth (20\%) of research undertaken in Australia. Other countries included Spain (12\%), Belgium (12\%), Italy (8\%), Netherlands, Canada, India, Bosnia, France, Austria, Poland, South Korea and Israel (0.4\%). Interestingly, none of the selected studies was carried out in the United Kingdom, indicating a gap in geographical location.

\section{2: Methodological Consideration}

All 25 studies (100\%) included a survey. These were carried out on either an online platform or with pen and paper. Twenty-two studies $(88 \%)$ used at least one validated scale (Table 5) with 20 studies (80\%) including at least two different validated scales. Seven studies (28\%) implemented validated measures but also included their own self-created scales as part 
of their surveys. The measures used across these studies greatly varied, indicating the diverse nature of this field (see Appendix 1). Nine validated scales were evident in more than one study (see Table 5).

Table 5

Table of Validated Scales

\begin{tabular}{|c|c|c|}
\hline Name of validated scale & $\begin{array}{l}\text { Number of } \\
\text { studies }\end{array}$ & Author (s) \\
\hline $\begin{array}{l}\text { Centre for Epidemiologic Studies } \\
\text { Depression Scale }\end{array}$ & 3 & $\begin{array}{l}\text { Rosenthal et al., 2016; } \\
\text { Walburg et al., 2016; } \\
\text { Frison and Eggermont, } \\
2017\end{array}$ \\
\hline $\begin{array}{l}\text { Sociocultural Attitudes Towards } \\
\text { Appearance Scale }\end{array}$ & 3 & $\begin{array}{l}\text { Cohen et al., 2017; } \\
\text { Harrison and Hefner, } \\
\text { 2014; McLean et al., } 2015\end{array}$ \\
\hline The Body Image State Scale & 2 & $\begin{array}{l}\text { Kleemans et al., 2018; } \\
\text { Calvete et al., } 2015\end{array}$ \\
\hline Objectified Body Consciousness Scale & 2 & $\begin{array}{l}\text { Cohen et al., 2017; } \\
\text { Harrison and Hefner, } 2014\end{array}$ \\
\hline Eating Disorder Inventory & 2 & $\begin{array}{l}\text { Cohen et al., 2017; } \\
\text { McLean et al., } 2015\end{array}$ \\
\hline The Photo Manipulation Scale & 2 & $\begin{array}{l}\text { Cohen et al, 2017; } \\
\text { Lonergan et al, } 2018\end{array}$ \\
\hline
\end{tabular}




\begin{tabular}{|l|l|l|}
\hline The Photo Investment Scale & 2 & $\begin{array}{l}\text { Cohen et al, 2017; } \\
\text { Lonergan et al, 2018 }\end{array}$ \\
\hline Narcissistic Personality Inventory & 2 & $\begin{array}{l}\text { Errasti et al, 2017; } \\
\text { Blachnio and Przepiorka, } \\
\end{array}$ \\
\hline Fear of Missing Out Scale & 2018 \\
& 2 & $\begin{array}{l}\text { Tomczyk and Selmanagic- } \\
\text { Lizde, 2018; Blachnio and } \\
\text { Przepiorka, 2018 }\end{array}$ \\
\hline
\end{tabular}

$16 \%$ of the literature utilised stimulus materials in the form of photographs. Only two studies used mixed methods, including a focus group and an interview as methods alongside surveys. This indicates a clear gap in the literature for more qualitative methods to be used in further research within this field.

\section{3: Theoretical Frameworks Employed}

Seven papers $(28 \%)$ clearly articulated a theoretical framework at the outset of their study. All seven papers referred to their framework when discussing findings. Seven papers (28\%) briefly mentioned a theoretical framework in their introduction but did not make reference to or evaluate their findings in line with this perspective. Eleven studies (44\%) did not position their study within any theoretical framework. Table 6 specifies a list of embedded frameworks, mentioned frameworks or indicates if no framework was used across the selected studies. 
Table 6

Theoretical Frameworks Identified

\begin{tabular}{|c|c|c|c|}
\hline Paper & Theoretical framework & Status & Author (s) \\
\hline 1 & Social Cognitive Theory & Mentioned & Kleemans et al., 2018 \\
\hline 2 & Social Comparison Theory & Mentioned & Fardouly and Rapee, 2019 \\
\hline 3 & Warranting Theory & Embedded & Vendemia and DeAndrea, 2018 \\
\hline 4 & Objectification Theory & Embedded & Cohen et al., 2017 \\
\hline 5 & None & & Mills et al., 2018 \\
\hline 6 & None & & Lonergan et al., 2018 \\
\hline 7 & Social Comparison Theory & Embedded & Marengo et al., 2018 \\
\hline 8 & Self-Presentation Theory & Mentioned & $\begin{array}{l}\text { Balakrishman and Griffiths, } \\
2017\end{array}$ \\
\hline 9 & Social Comparison Theory & Embedded & Harrison and Hefner, 2014 \\
\hline 10 & $\begin{array}{l}\text { Sociocultural Theories of } \\
\text { Body Dissatisfaction }\end{array}$ & $\begin{array}{l}\text { Mentioned } \\
\text { Generally }\end{array}$ & McLean et al., 2015 \\
\hline 11 & None & & Errasti et al., 2017 \\
\hline 12 & None & & Nesi and Prinstein, 2015 \\
\hline 13 & None & & Rosenthal et al., 2016 \\
\hline 14 & None & & Tomczyk and Lizde, 2018 \\
\hline 15 & Self-Escape Theory & Embedded & Walburg et al., 2015 \\
\hline 16 & $\begin{array}{l}\text { Uses and Gratifications } \\
\text { Theory }\end{array}$ & Mentioned & Wang et al., 2018 \\
\hline 17 & Expectancy Theory & Mentioned & Boursier and Manna, 2018 \\
\hline 18 & Mood Management Theory & Embedded & Frison and Eggermont, 2017 \\
\hline
\end{tabular}




\begin{tabular}{|l|l|l|l|}
\hline 19 & None & & Bourgeois et al., 2014 \\
\hline 20 & Social Cognitive Theory & Mentioned & Lenne et al., 2018 \\
\hline 21 & None & & Calvete and Gamez-Guadix, \\
& & & 2015 \\
\hline 22 & None & & Ziv and Kiasi, 2016 \\
\hline 23 & None Self- & Embedded & Meier and Gray, 2013 \\
\hline 24 & Objectification $/$ & & \\
\hline & Objectification Theory & & Weinstein, 2018 \\
\hline
\end{tabular}

Three theoretical frameworks appear in more than one study - Social Comparison Theory, Objectification Theory and Social Cognitive Theory.

\section{4: Themes}

$48 \%$ of studies focused on 'Social Network Sites' or 'Social Media' in general, using the term broadly and applying this to a range of online platforms with no particular focus on any singular SNS. $36 \%$ of the studies focused their research on Facebook. $16 \%$ of studies focused their research on Instagram. No papers exclusively focused on Snapchat although one paper included Snapchat briefly in their data collection along with other SNS. These findings indicate that much of the literature has focused on SNS in general, but little is known as to the individual relationships of particular SNS. Facebook has had a more significant investigation, and Instagram is just in its emergence of exploration. Snapchat investigations are scant.

Figure 2 presents the three main themes that were found across the literature. 


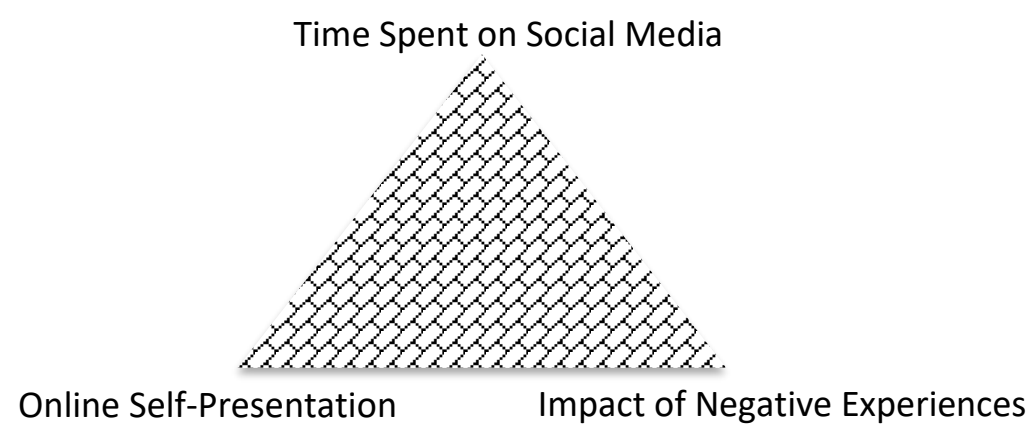

Figure 2: Main themes found across the literature

Time Spent on Highly Visual Social Media. Fifteen studies (60\%) investigate the relationship between the amount of time spent on social media and facets of wellbeing. Three studies $(20 \%)$ found higher social media usage in terms of time was beneficial to wellbeing. Contrastingly, thirteen studies $(87 \%)$ report a negative impact on individuals with four studies $(27 \%)$ stipulating that no relationship exists.

Positive Relationship. Studies that identified any positive link between social media use and mental health were limited. They also varied with regards to the particular strand of mental health they were exploring with some using 'wellbeing' as an overarching area of focus. With the three studies that found any positive influence, it is interesting to note that all three also found negative connections. No studies exclusively reported positive findings. Weinstein's (2018) results indicate that adolescents who spend time on social media feel an enhanced social connection, a greater sense of acceptance, more inspired and more relaxed due to being entertained by content. These positives, however, have negative counterparts, termed by Weinstein (2018) as 'The Social Media See-Saw.' She reports that adolescents who use social media also feel disconnected and isolated, concerned about others' judgements, distress, envy and boredom. Similar to Weinstein (2018), Errasti et al. (2017) found both positive and 
negative results. Their data indicates that moderate use of social media can facilitate the expression of empathy towards others. Adversely, heavy use, coined as 'addictive use,' is related to decreased levels of empathy. Ziv and Kiasi (2016) is the only study from the three to explore the relationship between HVSM and wellbeing, using a single social media platform, in this case, Facebook. Ziv and Kiasi (2016) $(\mathrm{n}=200)$ found that there was a statistically significant relationship between Facebook use and psychological wellbeing. Ziv and Kiasi (2016) identified, using regression analysis, that the only significant predictor of this relationship was the depth of engagement with this platform. The frequency and duration of Facebook use did not significantly predict psychological wellbeing. Their data indicates that the extent to which a young person engages in activities such as 'sharing information' or 'commenting' on content posted online is more likely to impact their wellbeing than merely scrolling through content.

Negative Relationship. Thirteen studies (87\%) report a negative relationship between social media use and various facets of wellbeing. A proportion (ten papers) explore increased loneliness, depression, low mood, decreased self-esteem with the remaining studies focused on body image and narcissism. Two studies look at an emerging term, FOMO, the Fear Of Missing Out and its emotional impact.

Two studies found the same detrimental impact of social media use on body image. McLean et al. (2015) reported higher levels of body-related and eating concerns with adolescents who engaged in more social media activities. Marengo et al. (2018) did not just explore social media in general but focused on platforms that used visual content (Facebook, Instagram, Snapchat). They found that those participants who used visual social media 
expressed significantly greater dissatisfaction with their body image and also reported higher levels of emotional symptoms.

Wang et al. (2018) found that adolescents who are 'extensive active Facebook users,' users who post messages, videos, photos and comment on posts, experience increased levels of loneliness. Tomczyk and Selmanaagic-Lizde (2018) had similar findings, but they did not explore a single social media platform. Instead, social media was explored encompassing multiple platforms. Blachnio and Przepiorka's (2018) findings correlate positively with this study. Their data focused on Facebook and identified that Facebook addiction is related to the Fear of Missing Out in reality, (FOMO) and that FOMO is related to lower life satisfaction.

Four studies found that social media use is related to higher levels of depression. Frison and Eggermont's (2017) study focused on Instagram $(n=671)$. Findings indicate that increased time spent browsing Instagram and posting on Instagram, both are related to greater depressed mood. Lenne et al.'s (2018) results show no relationship between Instagram use and mental wellbeing $(n=1,983)$. Bourgeois (2014) found that those who checked Facebook more often than once a day reported a higher incidence of emotional difficulties and had higher scores for headaches, worry, tearfulness, nervousness and fear. Similarly, Lenne et al. (2018) found a statistically significant direct relationship between Facebook use and poor mental wellbeing. Walburg (2016) also found that the more time participants spent on Facebook, termed 'problematic Facebook use,' the higher their burnout scores. Nesi and Prinstein (2015) found that all participants who reported that they did not use social media had less depressive symptoms.

Online Self-Presentation. Ten studies (40\%) explore the trend of 'Selfies' and their relationship to various facets of wellbeing. Half of these examine research participants' own 
selfies, and half of the studies examine research participants viewing of other people's selfies. The aims of the studies differed between 1) the act of posting selfies and 2) the time invested in taking and editing the perfect selfie.

Posting Selfies. Boursier and Manna (2018) found that posting selfies served as a mode of 'reinforcement' with adolescents, allowing them to reveal the best part of themselves to others, resulting in improved status amongst peers, increased self-esteem and boosted selfconfidence. Cohen et al. (2018) had similar findings. Their research concurred with the positive relationship of posting selfies and the sense of 'positive reinforcement.' Although this research did not explicitly explore the strands of self-esteem or confidence, it did find a positive relationship between selfie-posting and body satisfaction. Mills et al. (2018) explored the effects of selfie-taking and posting on body image satisfaction and found a negative relationship, however, the different measurements of both selfie-posting behaviour and body satisfaction (or body image satisfaction as described in Mills et al. (2018) may account for these divergent findings. Their results also indicated that women who took a selfie and posted it to social media had increased levels of anxiety, decreased confidence and worsened selfimage.

Although Balakrishnan and Griffiths (2018) found a positive relationship between selfie posting and increased self-confidence from their focus groups, they raise concern over the sustainability of these increased levels of self-confidence, claiming that they could be a short-term effect and assert the need for future research in this area.

Photo Investment. Five of the six studies that explore selfies in their research all examine the theme of photo investment - the amount of time and effort invested by an individual to create the perfect selfie. Bussey et al. (2018) found that higher levels of photo investment with selfies, including photo manipulation, positively associated with body 
dissatisfaction in both males and females aged 17-40 years. These findings support McLean et al.'s (2015) previous research with an exclusively female adolescent cohort. A positive relationship was found between body concern and higher frequency of investment and manipulation of selfies. This negative association between photo investment and selfies has been expanded by Cohen et al. (2018). They not only confirmed decreased body satisfaction but also found this relationship was associated with an increased eating disorder. Half of these studies focus on the impact of viewing other people's highly invested selfies as opposed to the research participants own self-image. Even with the change of research focus, findings still highlight that photos that have induced higher levels of investment have a negative impact on body satisfaction (Kleemans et al., 2018; Vendemia and DeAndrea, 2018; Fardouly and Rapee, 2019). Interestingly, $60 \%$ of these papers exclusively use females as their research participants. Little is known at present as to whether these findings are transferable to the male population.

Impact of Negative Experiences on Social Media. Two studies explored the relationship between negative social media experiences and mental health. Both studies found a negative impact. Calvete et al. (2015) focused on Cyberbullying, the harassment of individuals online, and found that Cyberbullying increased levels of depression. Similarly, Rosenthal et al. (2016) focused on Facebook, and the results indicate that those participants who reported negative Facebook experiences had greater depressive symptoms. 


\section{Discussion}

The primary area of interest was to find literature that explored HVSM and its relationship with young people's mental health. The five objectives of this scoping review will be used to discuss the findings.

\section{Objective 1: To explore what HVSM platforms have a body of existing research in relation to young people's mental health.}

This review found that a substantial proportion of research has been conducted into the crossover platform, Facebook. The volume of research could be attributed to the fact that Facebook is the most mature platform, created in 2003, seven years prior to Instagram. The newer platforms, to date, are under-explored. This review found a rapidly emerging volume of literature in a brief timespan, indicating a growth of interest in this field. It was clear that Instagram is an emerging area for research. Still, Snapchat remains largely under-investigated, meaning it is unclear at present if there is any relationship between the use of this platform on young people's mental health.

Findings from this review also indicate that a large proportion of papers group social media together with only a minority investigating a singular platform's relationship. Although there is an overlap with social media platforms, each site offers a unique set of attributes. Grouping them together for investigation does not provide a nuanced perspective of any one particular platform. Individuals do not necessarily use the same combination of online platforms or may dedicate themselves to a singular platform. This review found that nearly half of the included studies grouped social media platform use together for their investigation. This heterogeneity makes a comparison of results challenging to interpret. 
It is also evident that there is a diverse range of exploration across these platforms, indicating that there is no unified idea of how to study social media or its relationship on mental health. The multiplicity of strands investigated within this field meant that finding common themes and comparing findings was exceedingly difficult.

Objective 2: To explore the age range and gender of study participants in existing research.

It is evident from the current review that age range varies. It was clear from the screening process that there was a significant proportion of literature that did explore an older age range. However, the inclusion of these studies in this review would have altered the scope of the synthesis, skewing it towards an older demographic, which was not the original intention. Not only does this review indicate that a greater body of research needs to be conducted with the newer HVSM platforms, but it also indicates the need for research that focuses explicitly on 14-18-year olds within this field.

Regarding gender, the screening process highlighted a prominence placed on female participants, with $32 \%$ of studies exclusively focusing on the female gender. This scoping review has revealed that the male population is under-researched in this area.

\section{Objective 3: To explore what study methods have been implemented when researching the relationship between HVSM and young people's mental health.}

It is evident from this review that quantitative methods predominate. Data collection using surveys and analysis of statistical evidence is strongly apparent. This gives exceptional 
breadth to findings; however, the depth and context are less visible as a result (Jugenheimer et al., 2014).

The singular study that uses Focus Groups as part of their methods has a sample of 148 participants. Seven focus groups were carried out with the shortest time recorded as 23 minutes. It is questionable how transferable insights could be yielded from such large focus groups (average 21 participants) in such a short space of time. Additional work should consider employing a more granular exploration of participants' experiences using either interviews or smaller Focus Groups.

Objective 4: To explore relationships between inherent features of HVSM and young people's mental health, specifically the time spent using HVSM, the act of taking selfies and the use of filters on images.

The terms 'Mental Health' and 'Wellbeing' are not singular concepts but are multifaceted and encompass a range of attributes. This is reflected in the diversity of study aims and their findings. While these terms are holistic in intention, research to date is less exhaustive in the particular facets of mental health that they explore. Some of the relationships explored have mixed findings.

Time spent using HVSM: Young people who spend more time on social media sites were found to be more relaxed and felt a greater sense of social connection and acceptance (Weinstein, 2018). Other studies found that the more time spent using social media sites, the greater the levels of loneliness and depression (Marengo et al., 2018; Frison and Eggermont, 2017). The majority of these studies explored this relationship with Facebook. It remains 
unclear as to what the relationship is between the amount of time spent on HVSM platforms and mental health.

An emerging area of interest concerning time spent on social media and levels of loneliness and depression is the 'Fear of Missing Out' (FOMO). It was found that FOMO is related to lower life satisfaction (Blachnio and Przepiorka, 2018). This study based its research on Facebook with 16-53-year olds in Poland. There was an interesting juxtaposition within Tomczyk and Selmanaagic-Lizde's (2018) findings. Their data indicated that loneliness is one of the most prevalent factors that motivate individuals to log on to social media in the first place. Conversely, the intensity of using SNS was significantly related to FOMO, the increased sensation of loneliness in the real world. FOMO is strongly correlated with using SNS in the time designated for other activities, such as sleep and mealtimes. Exploration of FOMO through the use of HVSM with 14-18-year-old adolescents is needed to understand this relationship further.

Act of taking selfies: Taking and posting selfies was found to increase self-esteem, body satisfaction and self-confidence (Boursier and Manna, 2018; Cohen et al., 2018), however, it was also found to increase anxiety, body consciousness and decrease confidence and self-image (Mills et al., 2018; Balakrishnan and Griffiths, 2018).

Use of filters: Photo manipulation and digital filters are emerging as areas of interest. All studies that investigated the alteration of photos explored the relationship with body image/body dissatisfaction and found negative connections (Cohen et al., 2-18; Mills et al., 2018; Bussey et al., 2018; Kleemans et al., 2018; Vendemia and De Andrea, 2019; Harrison and Hefner, 2014). There has been very little research invested in other aspects of mental health, such as the relationship between digital filters and anxiety or depression. Five studies used images, alterations or filters in their surveys. No studies used images or filters as stimulus 
material for interviews or focus groups. The only study found to briefly explore selfiemodification and levels of anxiety (Mills et al., 2018) used a survey, was based in Canada, had an entire female sample aged 16-29 years. This relationship remains unexplored with 14-18year olds in the United Kingdom using qualitative methods.

When exploring these relationships, it is important to note that the numbers of participants per study varied which it makes it uncertain in the absence of reproducible data to determine whether the statistics reflect a chance finding rather than an actual result. These studies also tended to use different survey measurements which reduced the comparability of findings on what appear to be similar constructs (e.g. body satisfaction and body image satisfaction). Future research would benefit from using established measurements to measure the same constructs, e.g. using the Photo Activities measure (McLean et al., 2015) to assess practices of taking and sharing selfies online.

\section{Objective 5: To explore what researchers have used as theoretical frameworks to inform their data interpretation.}

Dramaturgy and Hyperreality were deemed as relevant theoretical perspectives in the relationship between highly visual social media and young people's mental health. It was interesting to find that only $28 \%$ of studies incorporated any form of a theoretical framework. This review found that three theories were evident in more than one study.

Social Comparison Theory: This theory was developed in 1954 by psychologist Leon Festinger and suggested that people have an innate drive to evaluate themselves, often in comparison to others (Cherry, 2019). A key concept of social comparison theory is that individuals determine their own social and personal worth based on how they measure up against others in terms of 
wealth, intelligence, and success. With the progression of social media platforms, users can assert more tact and discretion when revealing personal information than ever before (Vogel et al., 2014). They can selectively post pictures and describe themselves in ways that best represent their ideal self-views (Rosenberg and Egbert, 2011). This perspective relates closely to the theme of Self-Presentation that was identified as a common thread in the literature. Selfpresentation, when a person tries to influence the perception of their image, is often used synonymously with Goffman's core concept of impression management within dramaturgy. With inconsistent findings evident in current research surrounding selfies and a lack of research with filters and mental health, future research could explore the relationship between these inherent features of HVSM and young people's mental health through the lens of dramaturgy.

Objectification Theory: This theory contends that an objectifying culture can create a heightened level of body self-consciousness among young people. (Fredrickson \& Roberts, 1997). The theory proposes that females, more so than males, are socialised to internalise an observer's perspective as their primary view of their physical selves. This perspective is referred to as 'self-objectification,' which leads many girls and women to habitually monitor their bodies' outward appearance. (Calogero, 2012). Many of the objectified images found on social media platforms are likely to be self-presentations, posted by the users themselves in the form of selfies. (Bell et al., 2018).

This ties closely to both theories from the original framework lens. Goffman's concept of impression management within dramaturgy refers to manipulating the impression of one's appearance (Gardner and Avolio, 1998). The inherent features of HVSM and the emphasis placed on sharing visuals, put pressure on users of HVSM to objectify themselves in what is deemed to be acceptable and 'liked.' According to objectification theory, the constant practice of digital manipulation and enhancement of physical features sets up standards of attractiveness for females that are impossible to realise (Aubrey, 2007). This relates to the emphasis placed 
on HVSM platforms to share images and videos that portray unreachable, non-human qualities; a key argument of Baudrillard's Hyperreality theory.

Social Cognitive Theory: This theory states that people learn by observing and imitating others and by positive reinforcement. This theoretical perspective posits that behavioural change is affected not only by personal factors and internal dispositions but also by environmental influences (Yoon and Tourassi, 2014). In relation to social media use, increased time spent using these platforms encourages users to view others posts and images and curate their profiles to receive 'likes' and personal gratification. This relates to the findings from the literature on photo investment and Baudrillard's Hyperreality theory. Findings showed that more time was being invested in creating the perfect photograph, what Baudrillard deems as a 'simulacrum,' an image without resemblance (Boundas, 1990). The more time people spend observing and imitating others, they are increasing the detachment from their own reality; they are blurring the lines between what is real and what is fantasy in a quest for 'likes' and affirmation. As the findings from literature focus primarily on photo investment and bodyimage, future research could explore other aspects of mental health through the original framework lens.

\section{Implications for Research and Practice}

With adolescents immersing such proportions of their daily lives in highly visual social media, it is imperative that we understand the relationship of its use on mental health. It is clear from this review that research at present is both scarce and unclear. There also appears to be a need for valid and reliable measurements of HVSM behaviours, and for these measurements to be used with validated mental health measurements to better examine the relationships between these constructs. The consistent use of these measurements would then allow 
enhanced comparability of findings across studies. There also appears to be scant qualitative literature available to explore in more depth how these relationships manifest in everyday life.

The first limitation of this review is that it did not include studies exclusively focused on the 19+ age range. This is valuable research as it may have helped to explain some of the above relationships. A second limitation concerns the use of Google Scholar. Google Scholar has been found to lack the precision and stability of bibliographic databases, and the search algorithms it uses can lead to unintended bias in the publications identified (Bates et al., 2016). An additional limitation is that the terminology associated with the field of social media is rapidly evolving and heterogeneous. This has implications for those researching the literary landscape as there will be a multitude of search terms available. It also means that potential sources of literature could be missed.

Given the fact that the majority of literature is quantitative with their methods, one would have hoped to have used this scoping review as a foundation for a more systematic synthesis, i.e. a meta-analysis. However, due to the heterogeneity of scales and variables and the attributes that individual papers explored, many papers would not have been captured in a systematic review which reflects the merit of performing this scoping exercise.

As a precursor to designing interventions to improve the mental health of young people where HVSM has been detrimental, it seems imperative to evaluate, in greater depth, the nature of the relationships using methodologies that can explore and delve deeper into lived experience and the emotional impact of HVSM. 


\section{Conclusion}

This scoping review supports Best et al.'s (2014) assertion that the relationship and influence of highly visual social media on wellbeing and mental health remains unclear. Highly visual social media is current, and research into its use is emerging as an increasing area of interest. HVSM encourages users to be artists and designers to showcase their daily lives through the use of selective images. Online lives can be curated, and reality modified until an idealised life is portrayed. Research needs to explore the impact this dual existence has on mental health, particularly with adolescents in the United Kingdom. 


\section{Reference}

Action Mental Health. (2018). Mental Health in Northern Ireland.

Website: https://www.amh.org.uk/wp-content/uploads/2018/02/Briefing-MentalHealth-Crisis-in-Northern-Ireland.pdf

American Psychological Association. (2019). Mental Health Issues Increased Significantly in Young Adults Over Last Decade. Website: https://www.apa.org/news/press/releases /2019/03/mental-health-adults

Arksey, H., \& O’Malley, L. (2005). Scoping studies: Towards a Methodological Framework. International Journal of Social Research Methodology, 8(1), 19-32. doi.org/10.1080/1364557032000119616

Armstrong, R., Hall, B., Doyle, J., \& Waters, E. (2011). 'Scoping the scope' of a cochrane review, Journal of Public Health, 33(1), 147-150. doi.org/10.1093/pubmed/fdr015

Aubrey, J. (2007). The Impact of Sexually Objectifying Media Exposure on Negative Body Emotions. Mass Communication and Society, 10(1), 1-23. doi.org/10.1080/15205430709337002

Balakrishnan, J., Griffiths, M. (2018). An exploratory study of "selfitis" and the development of the Selfitis Behaviour Scale. International Journal Mental Health Addict, 16(3), 22-736. doi.org/10.1007/s11469-017-9844-x

Bates, J., Best, P., McQuilkin, J., \& Taylor, B. (2016). Will Web Search Engines Replace Bibliographic Databases in the Systematic Identification of Research? Journal of Academic Librarianship. doi.org/10.1016/j.acalib.2016.11.003

Battisby, A. (2019). The Latest UK Social Media Statistics for 2019.

Website: https://www.avocadosocial.com/latest-social-media-statistics-anddemographics-for-the-uk-in-2019/

Bell, B., Cassarly, J., \& Dunbar, L. (2018). Selfie-objectification: Self-objectification and 
positive feedback ("likes") are associated with frequency of posting sexually objectifying self-images on social media. Body Image, 24, 83-89. doi.org/10.1016/j.bodyim.2018.06.005

Best, P., Manktelow. R., \& Taylor, B. (2014). Online communication, social media and adolescent wellbeing: A systematic narrative review. Children and Youth Services Review, 41, 27-36. doi.org/10.1016/j.childyouth.2014.03.001

Błachnio, A., \& Przepiórka, A. (2018). Facebook intrusion, fear of missing out, narcissism, a and life satisfaction: A cross-sectional study, Psychiatry Research, 259, 514-519. doi.org/ 10.1016/j.psychres.2017.11.012

Boundas, G. (1990) The logic of sense. New York: Columbia University Press

Bourgeois, A., Bower, J., \& Carroll, A. (2014). Social Networking and the Social and Emotional Wellbeing of Adolescents in Australia. Australian Journal of Guidance and Counselling, 24, 167-182. doi.org/10.1017/jgc.2014.14

Boursier, V., \& Manna, V. (2018). Selfie expectancies among adolescents: construction and validation of an instrument to assess expectancies toward selfies among boys and girls. Frontiers in Psychology, 9, 839. doi.org/10.3389/fpsyg.2018.00839

Calogero, R. (2012) Objectification theory, self-objectification, and body image. In:

Cash, T. ed. Encyclopedia of Body Image and Human Appearance. Academic Press, $574-580$

Calvete, E., Orue, I., \& Gamez-Guadix, M. (2015). Cyberbullying victimization and depression in adolescents: The mediating role of body image and cognitive schemas in a one-year prospective study. European Journal on Criminal Policy and Research, 22, 271-284. doi.org/10.1007/s10610-015-9292-8

Cherry, K. (2019). Social Comparison Theory in Psychology. Website: https://www.verywellmind.com/what-is-the-social-comparison-process-2795872 
Chiu, A. (2018). More Than 250 People Worldwide Have Died Taking Selfies, The Washington Post, Website: https://www.stuff.co.nz/travel/traveltroubles/107588881/more-than-250-people-worldwide-have-died-taking-selfies'

Clement, J. (2019). Global Mobile Social Network Penetration Rate. Website: https://www.statista.com/statistics/412257/mobile-social-penetration-rate-region/

Cohen, R., Newton-John, T., \& Slater, A. (2018). 'Selfie'-objectification: The role of selfies in 530 self-objectification and disordered eating in young women. Computers in Human Behaviour, 79, 68-74. doi.org/10.1016/j.chb.2017.10.027

Constine, J. (2017). The Difference Between Good and Bad Facebooking. Website: https://techcrunch.com/2017/12/14/active-vs-passive-social-media/

Constine, J. (2018). Stories Are Growing 15X Faster Than Feeds. Website: https://techcrunch.com/2018/05/02/stories-are-about-to-surpass-feed-sharing-nowwhat/

Daudt, H., Mossel, C., Scott, S. (2013). Enhancing the scoping study methodology: a large, inter-professional team's experience with Arksey and O'Malley's framework. BMC Medical Research Methodology, 13, 13-48. doi.org/10.1186/1471-2288-13-48

Devika, S. (2016). Hyperreality. Website: https://drdevika.wordpress.com/2016/11/02 /hyperreality/

Digital 2020 Report. (2020). Digital in 2020. Website: https://wearesocial.com/digital-2020

Ellison, N., Heino, R., \& Gibbs, J. (2006). Managing Impression Online: Self-Presentation Processes in the Online Dating Environment. Journal of Computer-Mediated Communication, 11(2). doi.org/10.1111/j.1083-6101.2006.00020.x

Errasti, J., Amigo, I., \& Villadangos, M. (2017). Emotional uses of Facebook and Twitter: Its relation with empathy, narcissism, and self-esteem in adolescence. Psychological Reports, 120(6), 997-1018, doi.org/10.1177/0033294117713496 
Fardouly, J., \& Rapee, R. (2019). The impact of no-makeup selfies on young women's body image. Science Direct, Body Image, 28, 128-134. doi: 10.1016/j.bodyim.2019.01.006

Fitzpatrick, C., Lange, R., \& Radosh, J. (2016). Goffman's Self-Presentation Theory. Journal of Popular and American Culture, 1(1). Website: https://responsejournal.net/issue/2016-11/article/pilot-investigationgoffman\%E2\%80\%99s-self-presentation-theory-applied-linkedin

Fredrickson, B., \& Roberts, T. (1997). Objectification Theory. Psychology of Women Quarterly, 21(2). doi.org/10.1111/j.1471-6402.1997.tb00108.x

Frison, E., \& Eggermont, S. (2017). Browsing, posting, and liking on Instagram: the reciprocal relationships between different types of instagram use and adolescents' depressed mood. Cyberpsychology Behaviour Social Networking, 20(10), 603-609. doi.org/10.1089/cyber.2017.0156

Galderisi, S., Heinz, A., Kastrup, M., Beezhold, J., \& Sartorius N. (2015). Toward a new definition of mental health. World Psychiatry, 14, 231-233. doi.org/10.1002/wps.20231

Gardner, W., \& Avolio, B. (1998). The Charismatic Relationship: A Dramaturgical Perspective. Academy of Management Review, 23(1). doi.org/10.5465/amr.1998.192958

Global Digital Report. (2019). Global Internet Use Accelerates. Website: https://wearesocial.com/global-digital-report-2019

Goffman, E. (1959). The presentation of everyday life. New York: Doubleday

Gonzales, A., \& Hancock, J. (2011). Mirror, mirror on my facebook wall: effects of exposure to facebook on self-esteem. Cyberpsychology, Behaviour and Social Networking, 14, 79-83. doi.org/10.1089/cyber.2009.0411

Harrison, K., \& Hefner, V. (2014). Virtually perfect: Image retouching and adolescent body 
image. Media Psychology, 17, 134-153. doi.org/10.1080/15213269.2013.770354

Hendriks, C., Duss, S., \& Ercan, S. (2016). Performing politics on social media: the dramaturgy of an environmental controversy on Facebook. Environmental Politics, 25(6), 1102-1125. doi.org/10.1080/09644016.2016.1196967

Highfield, T., \& Leaver, T. (2016). Inftagrammatics and digital methods: Studying visual social media, from selfies and GIFS to memes and emoji. Website: https://espace.curtin.edu.au/bitstream/handle/20.500.11937/36939/240444.pdf?sequen ce $=2 \&$ is Allowed $=\mathrm{y}$

House of Commons. (2019). Impact of social media and screen use on young people's health, Website: https://publications.parliament.uk/pa/cm201719/cmselect/cmsctech/ 822/822.pdf

Jelenchick, L., Eickhoff, J., \& Moreno, M. (2013). Facebook Depression? Social networking site use and depression in older adults. Journal of Adolescent Health, 52, 128-130. doi: 10.1016/j.jadohealth.2012.05.008

Jugenheimer, D., Kelley, L., Hudson, J., \& Bradley, S. (2014). Advertising and Public Relations Research, 2nd Ed. Armonk, NY: M.E. Sharpe, Inc.

Kerrigan, F., \& Hart, A. (2016). Theorising digital personhood: a dramaturgical approach. Journal of Marketing Management, 32(17-18), 1701-1721. doi.org/10.1080/0267257X.2016.1260630

Kleemans, M., Daalmans, S., Carbaat, I., \& Anschütz, D. (2018). Picture perfect: the direct effect of manipulated Instagram photos on body image in adolescent girls. Media Psychology. 21(1), 93-110. doi.org/10.1080/15213269.2016.1257392

Lenne, O., Vandenbosch, L., Eggermont, S., Karsay, K., \& Trekels, J. (2018). Picture perfect lives on social media: a cross-national study on the role of media ideals in adolescent well-being. Media Psychology, 1-27. doi.org/10.1080/15213269.2018.1554494 
Levac, D., Colquhoun, H., \& O'Brien, K. (2010). Scoping studies: advancing the methodology. Implementing Science. 5:69. doi.org/10.1186/1748-5908-5-69

Lonergan, A., Bussey, K., Mond, J., Brown, O., Giffiths, S., Muray, S., \& Mitchison, D. (2018) Me, my selfie, and I: The relationship between editing and posting selfies and body dissatisfaction in men and women. Body Image, 28, 39-43. doi.org/10.1016/j.bodyim.2018.12.001

Marengo, D., Longobardi, C., \& Fabris M. (2018). Highly visual social media and internalizing symptoms in adolescence: the mediating role of body image concerns. Computers in Human Behaviour, 82, 63-69. doi.org/10.1016/j.chb.2018.01.003

Manning, P. (2005). Reinvigorating the tradition of symbolic interactionism. Symbolic Interactionism, 28(2), 167-173. doi.org/10.1525/si.2005.28.2.167

McCord, B., Rodebaugh, T., \& Levinson, C. (2014). Facebook: social uses and anxiety. Computers in Human Behaviour, 34, 23-27. doi.org/10.1016/j.chb.2014.01.020

McLean, S., Paxton, S., Wertheim, E., \& Masters, J. (2015). Photoshopping the selfie: self photo editing and photo investment are associated with body dissatisfaction in adolescent girls. International Journal of Eating Disorders, 48(8), 1132-1140. doi.org/10.1002/eat.22449

Mental Health Foundation. (2016). Mental Health in Northern Ireland: Fundamental Facts. Website: https://www.mentalhealth.org.uk/publications/mental-health-northernireland-fundamental-facts

Mills, S., Musto, S., Williams, L., \& Tiggemann, M. (2018). "Selfie” harm: effects on mood and body image in young women. Body Image, 27, 86-92. doi.org/10.1016/j.bodyim.2018.08.007

Mission Australia. (2019). Can we talk? Seven year youth mental health report. Website: 
https://www.missionaustralia.com.au/publications/youth-survey/1318-can-we-talkseven-year-youth-mental-health-report-2012-2018/file

Moher, D., Liberati, A., Tetzlaff, J., \& Altman, D. (2008). The PRISMA Group, Preferred reporting items for systematic reviews and meta-analyses: The PRISMA Statement. PLoS Medicine, 6. doi.org/10.1371/journal.pmed.1000097

National Health Service. (2018). Digital, Mental Health of Children and Young People in England. Website: https://digital.nhs.uk/data-andinformation/publications/statistical/mental-health-of-children-and-young-people-inengland/2017/2017

Nesi, J., \& Prinstein, M. (2015). Using social media for social comparison and feedbackseeking: gender and popularity moderate associations with depressive symptoms. Journal of Abnormal Child Psychology, 43(8), 1427-1438. doi.org/10.1007/s10802-015-0020-0

Ofcom. (2011). Children and Parents: media use and attitudes report. Website: https://www.ofcom.org.uk/_data/assets/pdf_file/0030/55479/children_and_ parents.pdf

Ofcom. (2019). Children and parents: Media use and attitudes report. Website: https://www.ofcom.org.uk/_data/assets/pdf_file/0024/134907/children-and-parentsmedia-use-and-attitudes-2018.pdf

Perloff, R. (2014). Social media effects on young women's body image concerns: Theoretical perspectives and an agenda for research. Sex Roles, 71, 363-377. doi.org/10.1007/s11199-014-0384-6

Peters, M., Godfrey, C., McInerney, K., Parker, D., \& Baldini, S. (2015). Guidance for conducting systematic scoping reviews. International Journal of Evidence Based Healthcare, 13(3), 141-146. doi.org/10.1097/XEB.0000000000000050 
Rideout. V., Foehr, U., \& Roberts, D. (2010). Generation M2: media in the lives of 8- to 18year-olds. Menlo Park: Kaiser Family Foundation. Website: https://files.eric.ed.gov/fulltext/ED527859.pdf

Rosenberg, J., \& Egbert, N. (2011). Online impression management: Personality traits and concerns for secondary goals as predictors of self-presentation tactics on Facebook. . Journal of Computer-Mediated Communication, 17, 1-18. doi.org/10.1111/j.10836101.2011.01560.x

Rosenthal, S., Buka, S., Marshall, B., Carey, K., \& Clark, M. (2016). Negative experiences on Facebook and depressive symptoms among young adults. The Journal of Adolescent Health, 59(5), 510-516. doi.org/10.1016/j.jadohealth.2016.06.023

Sample, I. (2019). Bedtime social media use may be harming UK teenagers. Website: https://www.theguardian.com/media/2019/feb/22/bedtime-social-media-use-may-beharming-uk-teenagers-study-says

Sawyer, R. (2011). The Impact of New Social Media on Intercultural Adaptation. Senior Honors Projects. Website: http://digitalcommons.uri.edu/srhonorsprog/242http:// digitalcommons.uri.edu/srhonorsprog/242

Shane, D. (2017). Social Media Is Getting More Competitive By The Day. Website: https://medium.com/the-mission/social-media-is-getting-more-competitive-by-theday-heres-how-to-stay-ahead-233a059ddfe0

Sorokowska, A., Oleszkiewicz, A., Frackowiak, T., Pisanski, K., Chmiel, A., \& Sorokowski, P. (2016). Selfies and personality: Who posts self-portrait photographs? Personality and Individual Differences, 90, 119-123. doi.org/10.1016/j.paid.2015.10.037

Srivastava, S., Upadhaya, P., Sharma, S., \& Gupta, K. (2018). Exploring factors behind offline and online selfie popularity among youth in India. Frontiers in Psychology, 9, 1403. doi.org/10.3389/fpsyg.2018.01403 
Statista. (2019) in Clement, J. (2019). Social media Statistics and Facts. Website: https://www.statista.com/topics/1164/social-networks/

Tomczyk, Ł., \& Selmanagic-Lizde, E. (2018). Fear of Missing Out (FOMO) among youth in Bosnia and Herzegovina - Scale and selected mechanisms. Children and Youth Services Review, 88, 541-549. doi.org/10.1016/j.childyouth.2018.03.048

Valkenburg, P., Peter, J., \& Schouten, A. (2006). Friend networking sites and their relationship to adolescents' well-being and social self-esteem. Cyberpsychology \& Behaviour, 9, 584-590. doi.org/10.1089/cpb.2006.9.584

Vendemia, M., \& DeAndrea, D. (2018). The effects of viewing thin, sexualized selfies on Instagram: Investigating the role of image source and awareness of photo editing practices. Body Image, 27, 118-127. doi.org/10.1016/j.bodyim.2018.08.013

Vogel, E., Rose, J., \& Roberts, L. (2014). Social Comparison, Social Media and Self-Esteem. Psychology of Popular Media Culture, 3(4), 206-222. doi.org/10.1037/ppm0000047

Volkinburg, N. (2018). Social Media Influencers and Hyperreality. Website: https://www.ninavanvolkinburg.com/blog/2018/04/24/social-media-influencersunreal-becomes-real

Walburg, V., Mialhes, A., \& Moncla, D. (2016). Does school-related burnout influence problematic Facebook use? Children and Youth Services Review, 61, 327-331. doi.org/10.1016/j.childyouth.2016.01.009

Wang, K., Frison, E., Eggermont, S., \& Vandenbosch, L. (2018). Active public Facebook use and adolescents' feelings of loneliness: Evidence for a curvilinear relationship. Journal of Adolescence, 67, 35-44. doi.org/10.1016/j.adolescence.2018.05.008

Weinstein, E. (2018). The social media see-saw: Positive and negative influences on adolescents' affective well-being. New Media \& Society, 20(10). doi.org/10.1177/1461444818755634 
World Health Organisation. (2014). Mental Health; a state of wellbeing. Website: https://www.who.int/features/factfiles/mental_health/en/

Yoon, H., \& Tourassi, G. (2014). Analysis of Online Networks to Understand Information Sharing Behaviours Through Social Cognitive Theory. Biomedical Science and Engineering Centre, doi: 10.1109/BSEC.2014.6867744

Ziv, I., \& Kiasi, M. (2016). Facebook's contribution to well-being among adolescent and young adults as a function of mental resilience. The Journal of Psychology, 150(4), 527-15. doi.org/10.1080/00223980.2015.1110556 


\section{APPENDIX 1:}

\begin{tabular}{|c|c|c|c|c|c|c|c|}
\hline $\begin{array}{l}\text { PAP } \\
\text { ER }\end{array}$ & $\begin{array}{c}\text { AUTHOR } \\
\text { S }\end{array}$ & $\begin{array}{c}\text { YEA } \\
\mathbf{R}\end{array}$ & $\begin{array}{c}\text { LOCATI } \\
\text { ON }\end{array}$ & $\begin{array}{c}\text { POPU- } \\
\text { LATIO } \\
\text { N }\end{array}$ & AIMS & $\begin{array}{c}\text { METHOD } \\
\text { S }\end{array}$ & RESULTS \\
\hline 1 & $\begin{array}{l}\text { Mariska } \\
\text { Kleemans, } \\
\text { Serena } \\
\text { Daalmans, } \\
\text { Ilana } \\
\text { Carbaat \& } \\
\text { Doeschka } \\
\text { Anschutz }\end{array}$ & 2018 & $\begin{array}{l}\text { Nether- } \\
\text { lands }\end{array}$ & $\begin{array}{l}144 \\
\text { Female } \\
14-18 \\
\text { years }\end{array}$ & $\begin{array}{l}\text { To } \\
\text { investigate } \\
\text { the effects of } \\
\text { exposure to } \\
\text { original and } \\
\text { manipulated } \\
\text { Instagram } \\
\text { photos of } \\
\text { peers on } \\
\text { adolescent } \\
\text { girls' body } \\
\text { image }\end{array}$ & $\begin{array}{l}\text { Snowball } \\
\text { sampling } \\
\text { Stimulus } \\
\text { materials } \\
\text { Online } \\
\text { Survey }\end{array}$ & $\begin{array}{l}\text { Girls exposed to the } \\
\text { manipulated photos } \\
\text { showed to have } \\
\text { significantly lower body } \\
\text { satisfaction. } \\
\text { Girls who have a higher } \\
\text { tendency to compare } \\
\text { themselves with others } \\
\text { have a lower body } \\
\text { image. }\end{array}$ \\
\hline 2 & $\begin{array}{l}\text { Jasmine } \\
\text { Fardouly } \\
\text { \& Ronald } \\
\text { Rapee }\end{array}$ & 2019 & Australia & $\begin{array}{l}175 \\
\text { Female } \\
18-25\end{array}$ & $\begin{array}{l}\text { To } \\
\text { investigate } \\
\text { the impact of } \\
\text { viewing no- } \\
\text { makeup } \\
\text { images vs } \\
\text { idealised }\end{array}$ & $\begin{array}{l}\text { Stimulus } \\
\text { materials } \\
\text { Online } \\
\text { Survey }\end{array}$ & $\begin{array}{l}\text { Findings suggest that } \\
\text { viewing idealised selfies } \\
\text { of attractive women } \\
\text { wearing makeup on } \\
\text { social media can have } \\
\text { an impact on women's } \\
\text { face related concerns. }\end{array}$ \\
\hline
\end{tabular}




\begin{tabular}{|c|c|c|c|c|c|c|c|}
\hline & & & & & $\begin{array}{l}\text { images on } \\
\text { mood, } \\
\text { appearance } \\
\text { satisfaction } \\
\text { and desire to } \\
\text { change }\end{array}$ & & $\begin{array}{l}\text { Viewing small number } \\
\text { of no makeup selfies } \\
\text { may counteract or } \\
\text { buffer negative impacts. }\end{array}$ \\
\hline 3 & $\begin{array}{l}\text { Megan } \\
\text { Vendemia, } \\
\text { David } \\
\text { DeAndrea }\end{array}$ & 2018 & $\begin{array}{l}\text { United } \\
\text { States }\end{array}$ & $\begin{array}{l}360 \\
\text { Female } \\
18-57 \\
\text { years }\end{array}$ & $\begin{array}{l}\text { To better } \\
\text { understand } \\
\text { how women } \\
\text { evaluate } \\
\text { other women } \\
\text { who post } \\
\text { selfies. } \\
\text { Explore } \\
\text { awareness of } \\
\text { photo editing } \\
\text { on sense of } \\
\text { self }\end{array}$ & $\begin{array}{l}\text { Stimulus } \\
\text { materials } \\
\text { Online } \\
\text { Survey }\end{array}$ & $\begin{array}{l}\text { When images were } \\
\text { presented as their peers } \\
\text { instead of models, they } \\
\text { ascribed less charitable } \\
\text { explanations for their } \\
\text { behaviour and evaluated } \\
\text { women more harshly. } \\
\text { Viewers awareness of } \\
\text { photo editing attenuated } \\
\text { negative effects. }\end{array}$ \\
\hline 4 & $\begin{array}{l}\text { Cohen, } \\
\text { Slater \& } \\
\text { Newton- } \\
\text { John }\end{array}$ & 2017 & Australia & $\begin{array}{l}259 \\
\text { Female } \\
18-29 \\
\text { years }\end{array}$ & $\begin{array}{l}\text { Stems from } \\
\text { Paper 10. To } \\
\text { investigate } \\
\text { how photo } \\
\text { manipulation } \\
\text { are related to } \\
\text { self- }\end{array}$ & $\begin{array}{l}\text { Online } \\
\text { Survey }\end{array}$ & $\begin{array}{l}\text { Greater selfie posting } \\
\text { was associated with } \\
\text { greater body } \\
\text { satisfaction. } \\
\text { Greater photo } \\
\text { investment was } \\
\text { associated with }\end{array}$ \\
\hline
\end{tabular}




\begin{tabular}{|c|c|c|c|c|c|c|c|}
\hline & & & & & $\begin{array}{l}\text { objectificatio } \\
\mathrm{n} \text {, body } \\
\text { satisfaction } \\
\text { and a drive } \\
\text { for thinness }\end{array}$ & & $\begin{array}{l}\text { increased eating } \\
\text { disorder and decreased } \\
\text { body satisfaction. } \\
\text { Overall social network } \\
\text { usage did not } \\
\text { demonstrate a } \\
\text { significant relationship. }\end{array}$ \\
\hline 5 & $\begin{array}{l}\text { Jennifer } \\
\text { Mills, } \\
\text { Sarah } \\
\text { Musto, } \\
\text { Lindsay } \\
\text { Williams } \\
\text { \& Marika } \\
\text { Tiggemann }\end{array}$ & 2018 & Canada & $\begin{array}{l}113 \\
\text { Female } \\
\text { 16-29 } \\
\text { years }\end{array}$ & $\begin{array}{l}\text { To test the } \\
\text { effect of } \\
\text { Selfie taking } \\
\text { on body } \\
\text { image and } \\
\text { mood in } \\
\text { women and } \\
\text { to test if } \\
\text { modifying a } \\
\text { selfie would } \\
\text { better mood } \\
\text { and body } \\
\text { image }\end{array}$ & $\begin{array}{l}\text { Experiment } \\
\text { al Task } \\
\text { Series of } \\
\text { visual } \\
\text { analogue } \\
\text { scales } \\
\text { (survey) }\end{array}$ & $\begin{array}{l}\text { Women who took a } \\
\text { selfie and posted it on } \\
\text { Social Media had } \\
\text { increased levels of } \\
\text { anxiety, decreased } \\
\text { confidence and lowered } \\
\text { perceived attractiveness } \\
\text { (worsened self-image) }\end{array}$ \\
\hline 6 & $\begin{array}{l}\text { Lonergan, } \\
\text { Bussey, } \\
\text { Mond, } \\
\text { Brown, } \\
\text { Griffiths, }\end{array}$ & 2018 & Australia & $\begin{array}{l}184 \\
\text { Male \& } \\
\text { Female } \\
17-40 \\
\text { years }\end{array}$ & $\begin{array}{l}\text { To } \\
\text { investigate } \\
\text { the } \\
\text { relationship } \\
\text { between body }\end{array}$ & $\begin{array}{l}\text { Online } \\
\text { Survey }\end{array}$ & $\begin{array}{l}\text { Body dissatisfaction } \\
\text { was positively } \\
\text { associated with photo } \\
\text { manipulation. Higher } \\
\text { levels of photo }\end{array}$ \\
\hline
\end{tabular}




\begin{tabular}{|c|c|c|c|c|c|c|c|}
\hline & $\begin{array}{l}\text { Murray \& } \\
\text { Mitchison }\end{array}$ & & & & $\begin{array}{l}\text { dissatisfactio } \\
\mathrm{n} \text { and } \\
\text { manipulation } \\
\text { of selfies. To } \\
\text { investigate } \\
\text { investment in } \\
\text { choosing a } \\
\text { selfie to post } \\
\text { to social } \\
\text { media and } \\
\text { reactions }\end{array}$ & & $\begin{array}{l}\text { investment were } \\
\text { associated with greater } \\
\text { body dissatisfaction. }\end{array}$ \\
\hline 7 & $\begin{array}{l}\text { Marengo, } \\
\text { Longobard } \\
\text { i, Fabris \& } \\
\text { Settanni }\end{array}$ & 2018 & Italy & $\begin{array}{l}523 \\
\text { Female } \\
\text { Averag } \\
\text { e age }= \\
14 \\
\text { years }\end{array}$ & $\begin{array}{l}\text { This study } \\
\text { aims to } \\
\text { evaluate the } \\
\text { association } \\
\text { between } \\
\text { social media } \\
\text { use, in } \\
\text { particular, } \\
\text { highly visual, } \\
\text { with body } \\
\text { image } \\
\text { concerns in } \\
\text { adolescents }\end{array}$ & $\begin{array}{l}\text { Online } \\
\text { Survey }\end{array}$ & $\begin{array}{l}\text { Adolescents reporting } \\
\text { use of social media } \\
\text { focusing on visual } \\
\text { content expressed } \\
\text { significantly greater } \\
\text { dissatisfaction with their } \\
\text { body image and report } \\
\text { greater levels of } \\
\text { emotional symptoms. } \\
\text { Frequent use of social } \\
\text { media has a negative } \\
\text { impact on body image } \\
\text { and mental health. }\end{array}$ \\
\hline
\end{tabular}




\begin{tabular}{|c|c|c|c|c|c|c|c|}
\hline 8 & $\begin{array}{l}\text { Balakrishn } \\
\text { an and } \\
\text { Griffiths }\end{array}$ & 2017 & India & $\begin{array}{l}\text { PHASE } \\
1 / 2 \\
225 / \\
400 \\
\text { Male \& } \\
\text { Female } \\
\text { Averag } \\
\text { e age = } \\
20\end{array}$ & $\begin{array}{l}\text { To explore } \\
\text { levels of } \\
\text { Selfie } \\
\text { Addiction. } \\
\text { To find sub- } \\
\text { dimensions } \\
\text { that aid } \\
\text { development } \\
\text { of Selfitis } \\
\text { across three } \\
\text { tiers of } \\
\text { addiction }\end{array}$ & $\begin{array}{l}\text { Mixed } \\
\text { Methods: } \\
\text { Focus } \\
\text { Groups } \\
\text { Survey }\end{array}$ & $\begin{array}{l}\text { A new Selfitis } \\
\text { Behaviour Scale was } \\
\text { developed. Six } \\
\text { components of Selfitis } \\
\text { were identified: } \\
1 \text { - Environmental } \\
\text { Enhancement } \\
2 \text { - Social Competition } \\
3 \text { - Attention Seeking } \\
4 \text { - Mood Modification } \\
5 \text { - Self-Confidence } \\
6 \text { - Social Conformity }\end{array}$ \\
\hline 9 & $\begin{array}{l}\text { Harrison } \\
\text { and Hefner }\end{array}$ & 2014 & $\begin{array}{l}\text { United } \\
\text { States }\end{array}$ & $\begin{array}{l}393 \\
\text { Male \& } \\
\text { Female } \\
\text { Averag } \\
\text { e age = } \\
15\end{array}$ & $\begin{array}{l}\text { To } \\
\text { manipulate } \\
\text { the idealness } \\
\text { construct via } \\
\text { an image } \\
\text { editing } \\
\text { treatment that } \\
\text { transformed } \\
\text { unretouched } \\
\text { photos to } \\
\text { retouched } \\
\text { photos and } \\
\text { measure the }\end{array}$ & $\begin{array}{l}\text { Stimulus } \\
\text { materials } \\
\text { Online } \\
\text { Survey }\end{array}$ & $\begin{array}{l}\text { There was a significant } \\
\text { increase in objectified } \\
\text { body consciousness and } \\
\text { decrease in body self- } \\
\text { esteem only in those } \\
\text { who viewed images as } \\
\text { explicitly identified as } \\
\text { retouched compared to } \\
\text { those who were } \\
\text { unaware }\end{array}$ \\
\hline
\end{tabular}




\begin{tabular}{|c|c|c|c|c|c|c|c|}
\hline & & & & & $\begin{array}{l}\text { effects on } \\
\text { body } \\
\text { perception }\end{array}$ & & \\
\hline 10 & $\begin{array}{l}\text { McLean, } \\
\text { Paxton, } \\
\text { Wertheim, } \\
\text { Masters }\end{array}$ & 2015 & Australia & $\begin{array}{l}101 \\
\text { Female } \\
\text { Averag } \\
\text { e age = } \\
13\end{array}$ & $\begin{array}{l}\text { 1) To } \\
\text { examine } \\
\text { relationships } \\
\text { between } \\
\text { social media } \\
\text { activities - } \\
\text { selfies, body } \\
\text { dissatisfactio } \\
\text { n, shape, } \\
\text { weight } \\
\text { 2) How photo } \\
\text { manipulation } \\
\text { is related to } \\
\text { body and } \\
\text { eating } \\
\text { concerns }\end{array}$ & Survey & $\begin{array}{l}\text { Higher levels of body } \\
\text { related and eating } \\
\text { concerns were found for } \\
\text { participants engaging in } \\
\text { more social media } \\
\text { related activities. } \\
\text { Positive relationships } \\
\text { between body concern } \\
\text { and higher frequency of } \\
\text { manipulation of photos } \\
\text { for online posting }\end{array}$ \\
\hline 11 & $\begin{array}{l}\text { Errasti, } \\
\text { Amigo, } \\
\text { Villadango } \\
\text { s }\end{array}$ & 2017 & Spain & $\begin{array}{l}503 \\
\text { Male \& } \\
\text { Female } \\
14-17 \\
\text { years }\end{array}$ & $\begin{array}{l}\text { To analyse } \\
\text { whether there } \\
\text { exists a } \\
\text { relationship } \\
\text { between } \\
\text { frequency }\end{array}$ & Survey & $\begin{array}{l}\text { Data indicates that } \\
\text { while addictive use of } \\
\text { SNS can be related to a } \\
\text { decrease in empathy, } \\
\text { moderate use of SNS } \\
\text { can facilitate the }\end{array}$ \\
\hline
\end{tabular}




\begin{tabular}{|c|c|c|c|c|c|c|c|}
\hline & & & & & $\begin{array}{l}\text { and style of } \\
\text { social } \\
\text { network sites } \\
\text { with } \\
\text { personalities }\end{array}$ & & $\begin{array}{l}\text { expression of empathy } \\
\text { towards others. }\end{array}$ \\
\hline 12 & $\begin{array}{l}\text { Nesi and } \\
\text { Prinstein }\end{array}$ & 2015 & $\begin{array}{l}\text { United } \\
\text { States }\end{array}$ & $\begin{array}{l}619 \\
\text { Male \& } \\
\text { Female } \\
12-16 \\
\text { years }\end{array}$ & $\begin{array}{l}\text { To explore if } \\
\text { higher levels } \\
\text { of tech based } \\
\text { social } \\
\text { comparison is } \\
\text { associated } \\
\text { with } \\
\text { depressive } \\
\text { symptoms }\end{array}$ & $\begin{array}{l}\text { Computer- } \\
\text { Assisted } \\
\text { Self } \\
\text { Interview } \\
\text { (survey) }\end{array}$ & $\begin{array}{l}\text { All participants who } \\
\text { reported that they did } \\
\text { not use technology had } \\
\text { less depressive } \\
\text { symptoms. }\end{array}$ \\
\hline 13 & $\begin{array}{l}\text { Rosenthal, } \\
\text { Buka, } \\
\text { Marshall, } \\
\text { Carey, } \\
\text { Clark }\end{array}$ & 2016 & $\begin{array}{l}\text { United } \\
\text { States }\end{array}$ & $\begin{array}{l}564 \\
\text { Male \& } \\
\text { Female } \\
12-17 \\
\text { years }\end{array}$ & $\begin{array}{l}\text { To examine } \\
\text { how negative } \\
\text { interactions } \\
\text { with others } \\
\text { on social } \\
\text { media may } \\
\text { be related to } \\
\text { depression }\end{array}$ & Survey & $\begin{array}{l}\text { Those who reported } \\
\text { negative Facebook } \\
\text { experiences had greater } \\
\text { odds of depressive } \\
\text { symptoms. }\end{array}$ \\
\hline 14 & $\begin{array}{l}\text { Tomczyk } \\
\text { and }\end{array}$ & 2018 & Bosnia & $\begin{array}{l}717 \\
\text { Male \& } \\
\text { Female }\end{array}$ & $\begin{array}{l}\text { To present } \\
\text { different } \\
\text { perspectives }\end{array}$ & Survey & $\begin{array}{l}\text { More than } 1 / 4 \text { said they } \\
\text { felt negative emotions } \\
\text { when offline. Almost } 1\end{array}$ \\
\hline
\end{tabular}




\begin{tabular}{|c|c|c|c|c|c|c|c|}
\hline & $\begin{array}{l}\text { Selmanagi } \\
\text { c-Lizde }\end{array}$ & & & $\begin{array}{l}\text { Averag } \\
\text { e age = } \\
13 \\
\text { years }\end{array}$ & $\begin{array}{l}\text { of the } \\
\text { perception of } \\
\text { FOMO }\end{array}$ & & $\begin{array}{l}\text { in } 3 \text { check SNS after } \\
\text { waking up. Similar } \\
\text { number eat evening } \\
\text { meal whilst using SNS. } \\
\text { Loneliness is one of the } \\
\text { most important factors } \\
\text { that motivates logging } \\
\text { in to SNS. } 1 \text { in } 5 \text { log in } \\
\text { to avoid thinking about } \\
\text { problems. }\end{array}$ \\
\hline 15 & $\begin{array}{l}\text { Walburg, } \\
\text { Mialhes, } \\
\text { Moncla }\end{array}$ & 2015 & France & $\begin{array}{l}286 \\
\text { Male \& } \\
\text { Female } \\
\text { Averag } \\
\text { e age = } \\
16 \\
\text { years }\end{array}$ & $\begin{array}{l}\text { To explore if } \\
\text { one or more } \\
\text { of the } \\
\text { dimensions } \\
\text { of burnout } \\
\text { affect } \\
\text { problematic } \\
\text { Facebook use }\end{array}$ & Survey & $\begin{array}{l}\text { Students with } \\
\text { problematic FB use } \\
\text { have higher burnout } \\
\text { scores than those with } \\
\text { average use. }\end{array}$ \\
\hline 16 & $\begin{array}{l}\text { Wang, } \\
\text { Frison, } \\
\text { Eggermont } \\
\text {, } \\
\text { Vandenbos } \\
\text { h }\end{array}$ & 2018 & Belgium & $\begin{array}{l}1188 \\
\text { Male \& } \\
\text { Female } \\
\text { Averag } \\
\text { e age = } \\
14\end{array}$ & $\begin{array}{l}\text { To } \\
\text { investigate } \\
\text { the } \\
\text { relationship } \\
\text { between } \\
\text { levels of use } \\
\text { of social }\end{array}$ & Survey & $\begin{array}{l}\text { Heavy FB users } \\
\text { experienced increased } \\
\text { loneliness. }\end{array}$ \\
\hline
\end{tabular}




\begin{tabular}{|c|c|c|c|c|c|c|c|}
\hline & & & & & $\begin{array}{l}\text { media and } \\
\text { levels of } \\
\text { loneliness }\end{array}$ & & \\
\hline 17 & $\begin{array}{l}\text { Boursier } \\
\text { and Manna }\end{array}$ & 2018 & Italy & $\begin{array}{l}646 \\
\text { Male \& } \\
\text { Female } \\
14-19 \\
\text { years }\end{array}$ & $\begin{array}{l}\text { To validate a } \\
\text { reliable } \\
\text { instrument } \\
\text { that can } \\
\text { identify } \\
\text { teenage } \\
\text { expectancies } \\
\text { about selfie } \\
\text { production }\end{array}$ & Survey & $\begin{array}{l}\text { Selfies are used as a } \\
\text { tool to manage self- } \\
\text { confidence and increase } \\
\text { self-esteem }\end{array}$ \\
\hline 18 & $\begin{array}{l}\text { Frison and } \\
\text { Eggermont }\end{array}$ & 2017 & Belgium & $\begin{array}{l}671 \\
\text { Male \& } \\
\text { Female } \\
\text { Averag } \\
\text { e age = } \\
15\end{array}$ & $\begin{array}{l}\text { To examine } \\
\text { the } \\
\text { relationship } \\
\text { between } \\
\text { Instagram } \\
\text { and } \\
\text { depression, } \\
\text { risks of its } \\
\text { use and } \\
\text { different } \\
\text { types of use }\end{array}$ & Surveys & $\begin{array}{l}\text { Instagram browsing was } \\
\text { related to greater } \\
\text { depressed mood in } \\
\text { adolescents. Depressed } \\
\text { mood was related to } \\
\text { more Instagram posting. } \\
\text { No relationship between } \\
\text { Instagram liking and } \\
\text { depression. }\end{array}$ \\
\hline
\end{tabular}




\begin{tabular}{|c|c|c|c|c|c|c|c|}
\hline 19 & $\begin{array}{l}\text { Bourgeois, } \\
\text { Bower, } \\
\text { Carroll }\end{array}$ & 2014 & Australia & $\begin{array}{l}1343 \\
\text { Male \& } \\
\text { Female } \\
11-18 \\
\text { years }\end{array}$ & $\begin{array}{l}\text { Social } \\
\text { networking } \\
\text { sites on } \\
\text { adolescent } \\
\text { wellbeing - } \\
\text { constructs of } \\
\text { virtual } \\
\text { connectednes } \\
\text { s }\end{array}$ & Survey & $\begin{array}{l}\text { Those who checked FB } \\
\text { more often than once a } \\
\text { day reported a higher } \\
\text { incidence of emotional } \\
\text { difficulties. Young } \\
\text { people participate in } \\
\text { online activities to build } \\
\text { connections to others in } \\
\text { adolescent years. } \\
\text { Higher scores for } \\
\text { headaches, worry, } \\
\text { tearfulness, nervousness } \\
\text { and fear. }\end{array}$ \\
\hline 20 & $\begin{array}{l}\text { De Lenne, } \\
\text { Vandenbos } \\
\text { ch, } \\
\text { Eggermont } \\
\text {, Karsay } \\
\text { and } \\
\text { Trekels }\end{array}$ & 2018 & $\begin{array}{l}\text { Austria, } \\
\text { Belgium, } \\
\text { Spain, } \\
\text { South } \\
\text { Korea }\end{array}$ & $\begin{array}{l}1983 \\
\text { Male \& } \\
\text { Female } \\
12-19 \\
\text { years }\end{array}$ & $\begin{array}{l}\text { To explore } \\
\text { the relations } \\
\text { between } \\
\text { Facebook } \\
\text { use, } \\
\text { Instagram } \\
\text { use, the } \\
\text { internalisatio } \\
\text { n of } \\
\text { professional, } \\
\text { social, sexual }\end{array}$ & Survey & $\begin{array}{l}\text { Adolescents reported } \\
\text { spending more time on } \\
\text { Insta than FB. They } \\
\text { reported having } \\
\text { internalised } \\
\text { professional, social and } \\
\text { romantic ideals. Direct } \\
\text { positive relation was } \\
\text { found between FB and } \\
\text { poor mental wellbeing. } \\
\text { No relationship found }\end{array}$ \\
\hline
\end{tabular}




\begin{tabular}{|c|c|c|c|c|c|c|c|}
\hline & & & & & $\begin{array}{l}\text { and romantic } \\
\text { ideals }\end{array}$ & & $\begin{array}{l}\text { between Insta and } \\
\text { mental wellbeing. }\end{array}$ \\
\hline 21 & $\begin{array}{l}\text { Calvete, } \\
\text { Orue, } \\
\text { Gamez- } \\
\text { Guadix }\end{array}$ & 2015 & Spain & $\begin{array}{l}1015 \\
\text { Male \& } \\
\text { Female } \\
14-18 \\
\text { years }\end{array}$ & $\begin{array}{l}\text { To } \\
\text { understand } \\
\text { the } \\
\text { mechanisms } \\
\text { through } \\
\text { which } \\
\text { Cyberbullyin } \\
\text { g leads to the } \\
\text { development } \\
\text { or } \\
\text { exacerbation } \\
\text { of depressive } \\
\text { symptoms }\end{array}$ & Survey & $\begin{array}{l}\text { Cyberbullying } \\
\text { worsened cognitive } \\
\text { schemas and body } \\
\text { image. Cyberbullying } \\
\text { increased depression. }\end{array}$ \\
\hline 22 & $\begin{array}{l}\text { Ziv and } \\
\text { Kiassi }\end{array}$ & 2016 & Israel & $\begin{array}{l}200 \\
\text { Male \& } \\
\text { Female } \\
13-26\end{array}$ & $\begin{array}{l}\text { To } \\
\text { investigate } \\
\text { the } \\
\text { relationship } \\
\text { between } \\
\text { Facebook use } \\
\text { and levels of } \\
\text { resilience }\end{array}$ & Survey & $\begin{array}{l}\text { Wellbeing and } \\
\text { resilience increases as } \\
\text { FB use grows. } \\
\text { Relationship } \\
\text { particularly evident } \\
\text { among participants with } \\
\text { low self-esteem. } \\
\text { Wellbeing is not } \\
\text { associated with greater } \\
\text { frequency and duration }\end{array}$ \\
\hline
\end{tabular}




\begin{tabular}{|c|c|c|c|c|c|c|c|}
\hline & & & & & & & $\begin{array}{l}\text { of FB use but only with } \\
\text { the depth of } \\
\text { engagement. }\end{array}$ \\
\hline 23 & $\begin{array}{l}\text { Blachnio } \\
\text { and } \\
\text { Przepiorka }\end{array}$ & 2018 & Poland & $\begin{array}{l}360 \\
\text { Male \& } \\
\text { Female } \\
16-53\end{array}$ & $\begin{array}{l}\text { To explore } \\
\text { Facebook } \\
\text { intrusion with } \\
\text { life } \\
\text { satisfaction, } \\
\text { FOMO and } \\
\text { narcissism }\end{array}$ & Survey & $\begin{array}{l}\text { Higher levels of FB use } \\
\text { are related to higher } \\
\text { levels of narcissism. } \\
\text { Facebook addiction is } \\
\text { related to FOMO. } \\
\text { FOMO related to lower } \\
\text { life satisfaction. }\end{array}$ \\
\hline 24 & $\begin{array}{l}\text { Meier and } \\
\text { Gray }\end{array}$ & 2013 & $\begin{array}{l}\text { United } \\
\text { States }\end{array}$ & $\begin{array}{l}103 \\
\text { Female } \\
12-18 \\
\text { years }\end{array}$ & $\begin{array}{l}\text { To } \\
\text { investigate } \\
\text { whether } \\
\text { higher } \\
\text { Facebook use } \\
\text { correlates } \\
\text { with lower } \\
\text { weight } \\
\text { satisfaction } \\
\text { and whether } \\
\text { higher } \\
\text { Facebook } \\
\text { appearance } \\
\text { exposure } \\
\text { correlates }\end{array}$ & Survey & $\begin{array}{l}\text { Positively correlated } \\
\text { with drive for thinness, } \\
\text { self-objectification and } \\
\text { internalisation of thin- } \\
\text { idea. Significant } \\
\text { difference between non- } \\
\text { FB users and FB users - } \\
\text { FB users scored higher } \\
\text { for self-objectification } \\
\text { and physical appearance } \\
\text { comparison. No } \\
\text { correlation between } \\
\text { time on FB and Body } \\
\text { Image. No relationship } \\
\text { between time on }\end{array}$ \\
\hline
\end{tabular}




\begin{tabular}{|c|c|c|c|c|c|c|c|}
\hline & & & & & $\begin{array}{l}\text { with lower } \\
\text { weight } \\
\text { satisfaction }\end{array}$ & & $\begin{array}{l}\text { internet and Body } \\
\text { Image. }\end{array}$ \\
\hline 25 & Weinstein & 2018 & $\begin{array}{l}\text { United } \\
\text { States }\end{array}$ & $\begin{array}{l}588 \\
\text { Male \& } \\
\text { Female } \\
\text { Averag } \\
\text { e age = } \\
15 \\
\text { years }\end{array}$ & $\begin{array}{l}\text { To identify } \\
\text { positive and } \\
\text { negative } \\
\text { Social Media } \\
\text { experiences }\end{array}$ & $\begin{array}{l}\text { Mixed } \\
\text { Methods: } \\
\text { Online } \\
\text { Survey } \\
\text { Interviews }\end{array}$ & $\begin{array}{l}\text { Adolescents report } \\
\text { social media use as a } \\
\text { generally positive } \\
\text { experience. }\end{array}$ \\
\hline
\end{tabular}


APPENDIX 2: Table of Measures and Scales

\begin{tabular}{|c|c|}
\hline PAPER & SCALE \\
\hline 1 & $\begin{array}{l}\text { The Body Image State Scale (Cash et al., 2002) } \\
\text { The Iowa-Netherlands Comparison Orientation Measure (Gibbons and Buunk, } \\
\text { 1999) }\end{array}$ \\
\hline 2 & $\begin{array}{l}\text { The Self Discrepancy Index (Dittmar et al., 1996) } \\
\text { The State Appearance Comparison Scale (Tiggemann and McGill, 2004) }\end{array}$ \\
\hline 3 & $\begin{array}{l}\text { The Importance of Thinness Subscale (Forbes et al., 2007) } \\
\text { Photo Modification Scale (DeAndrea and Carpenter, 2016) }\end{array}$ \\
\hline 4 & $\begin{array}{l}\text { The Photo Activities Measure (McLean et al., 2015) } \\
\text { The Photo Investment Scale (McLean et al., 2015) } \\
\text { The Photo Manipulation Scale (McLean et al., 2015) } \\
\text { The Internalisation General Subscale of the Sociocultural Attitudes Towards } \\
\text { Appearance (Thompson et al., 2004) } \\
\text { The Appearance Evaluation Subscale of the Multidimensional Body-Self } \\
\text { Relations Scale (Cash, 2000) } \\
\text { The Body Surveillance subscale of the Objectified Body Consciousness Scale } \\
\text { (McKinley and Hyde, 1996) } \\
\text { The Drive for Thinness and Bulimia Subscales of the Eating Disorder } \\
\text { Inventory (Garner, 2004) }\end{array}$ \\
\hline 5 & A Series of Visual Analogue Scales (does not specify) \\
\hline 6 & $\begin{array}{l}\text { Photo Manipulation and Investment Scales (McLean et al., 2015) } \\
\text { The Body Shape Satisfaction Scale (Pingitore et al., 1997) } \\
\text { The Self-Compassion Scale (Raes et al., 2011) }\end{array}$ \\
\hline
\end{tabular}




\begin{tabular}{|c|c|}
\hline 7 & $\begin{array}{l}\text { The Body Shape Questionnaire (Cooper et al., 1987) } \\
\text { Strengths and Difficulties Questionnaire (Goodman et al., 1998) }\end{array}$ \\
\hline 8 & The Selfitis Behaviour Scale (specifically designed) \\
\hline 9 & $\begin{array}{l}\text { Sociocultural Attitudes Towards Appearance (Thompson et al., 2004) } \\
\text { The Objectified Body Consciousness Scale (McKinley and Hyde, 1996) } \\
\text { Physical Self-Description Questionnaire (Marsh et al., 19945) }\end{array}$ \\
\hline 10 & $\begin{array}{l}\text { Body Dissatisfaction subscale of the Eating Disorder Inventory (Garner, 2004) } \\
\text { Eating Disorder Examination Questionnaire (Fairburn, 1994) } \\
\text { Dutch Eating Behaviour Questionnaire (Van Strien et al., 1986) } \\
\text { Sociocultural Attitudes Towards Appearance (Thompson et al., 2004) }\end{array}$ \\
\hline 11 & $\begin{array}{c}\text { Basic Empathy Scale (Jolliffe and Farrington, 2006) } \\
\text { Narcissistic Personality Inventory (Raskin and Hall, 1979) } \\
\text { Rosenberg Self-Esteem Scale (Rosenberg, 1965) } \\
\text { Facebook Questionnaire (specifically designed) } \\
\text { Twitter Questionnaire (specifically designed) }\end{array}$ \\
\hline 12 & $\begin{array}{l}\text { The Short Mood and Feelings Questionnaire (Angold et al., 1995) } \\
\text { The Motivations for Electronic Interaction Scale (specifically designed) } \\
\text { Reassurance Seeking Scale (Joiner and Metalsky, 1995) } \\
\text { The Electronic Interaction Scale for Time (specifically designed) }\end{array}$ \\
\hline 13 & Centre for Epidemiologic Studies Short Depression Scale (Radloff, 1977) \\
\hline 14 & $\begin{array}{l}\text { Social Media Intensity Scale (Ellison, Steinfield and Lampe, 2007) } \\
\text { Fear of Missing Out Scale (Przbylski et al., 2013) } \\
\text { Summary of Social Media Use (Hetz et al., 2015) } \\
\text { Social Media Usage Urges Scale (Abel et al., 2016) } \\
\text { Bergen Facebook Addiction Scale (Andreassen et al., 2012) }\end{array}$ \\
\hline
\end{tabular}




\begin{tabular}{|c|c|}
\hline & Parents Control Scale (Tomczyk and Wasinski, 2017) \\
\hline 15 & $\begin{array}{l}\text { Internet Addiction Test (Widyanto and McMurran, 2004) } \\
\text { School Burnout Inventory (Salmela-Aro, Savolainen et al., 2009) } \\
\text { Centre for Epidemiologic Studies Depression Scale (Radloff, 1977) }\end{array}$ \\
\hline 16 & $\begin{array}{l}\text { The Active Public Facebook Use Subscale of the Multi-dimensional Scale of } \\
\text { Facebook Use (Frison and Eggermont, 2015) } \\
\text { The Loneliness Scale (deJong-Gierveld and Kamphuls, 1985) }\end{array}$ \\
\hline 17 & $\begin{array}{l}\text { The Selfie Frequency Scale (Manna and Boursier, 2017) } \\
\text { The Selfie Expectancies Scale (specifically designed) }\end{array}$ \\
\hline 18 & $\begin{array}{c}\text { Different Types of Instagram Use Scale (specifically designed) } \\
\text { Centre for Epidemiologic Studies Depression Scale (Radloff, 1977) }\end{array}$ \\
\hline 19 & $\begin{array}{c}\text { Youth Self-Report (Goodman, 1997) } \\
\text { Self in a Social Context Scale (Carroll and Bower, 2012) }\end{array}$ \\
\hline 20 & $\begin{array}{l}\text { Facebook and Instagram Use Scale (specifically designed) } \\
\text { Internalisation Scales (specifically designed) } \\
\text { The Mental Health Inventory (Rumpf et al., 2001) }\end{array}$ \\
\hline 21 & $\begin{array}{c}\text { Cyberbullying Questionnaire (Calvete et al., 2010) } \\
\text { Body Image States Scale (Cash et al., 2002) } \\
\text { Young Schema Questionnaire (Young, 2006) } \\
\text { Brief Symptom Inventory (Derogatis and Fitzpatrick, 2004) }\end{array}$ \\
\hline 22 & $\begin{array}{c}\text { Facebook Use Scale (specifically designed) } \\
\text { Ego Resilience Scale (Block and Kremen, 1996) } \\
\text { General Wellbeing Index (Hunt and McKenna, 1992) }\end{array}$ \\
\hline 23 & $\begin{array}{l}\text { Facebook Intrusion Questionnaire (Elphinston and Noller, 2011) } \\
\text { Fear of Missing Out Scale (Przbylski et al., 2013) }\end{array}$ \\
\hline
\end{tabular}




\begin{tabular}{|c|c|}
\hline & $\begin{array}{l}\text { Narcissistic Personality Inventory (Bazinska and Drat-Ruszczak, 2000) } \\
\text { Satisfaction with Life Scale (Diener et al., 1985) }\end{array}$ \\
\hline 24 & $\begin{array}{l}\text { Sociocultural Internalisation of Appearance Questionnaire for Adolescents } \\
\qquad \text { (Keery et al., 2004) } \\
\text { The Physical Appearance Comparison Scale (Thompson et al., 1991) } \\
\text { Body Esteem Scale for Adolescents and Adults (Mendelson et al., 2001) } \\
\text { Eating Disorder Inventory (Garner et al., 1983) } \\
\text { Self-Objectification Questionnaire (Noll and Fredreickson, 1998) } \\
\text { Total Internet and Facebook Use Scale (specifically designed) } \\
\text { Facebook Appearance Related Exposure Scale (specifically designed) }\end{array}$ \\
\hline 25 & (specifically designed) survey based on AP-NORC (2017) \\
\hline
\end{tabular}

